\title{
Aerosol solar radiative forcing near the Taklimakan Desert based on radiative transfer and regional meteorological simulations during the Dust Aerosol Observation-Kashi campaign
}

\author{
$\mathrm{Li} \mathrm{Li}{ }^{1}$, Zhengqiang $\mathrm{Li}^{1}$, Wenyuan Chang ${ }^{2}$, Yang $\mathrm{Ou}^{1}$, Philippe Goloub ${ }^{3}$, Chengzhe $\mathrm{Li}^{4}$, Kaitao $\mathbf{L i}^{1}$, Qiaoyun $\mathrm{Hu}^{3}$, \\ Jianping Wang ${ }^{1}$, and Manfred Wendisch ${ }^{5}$ \\ ${ }^{1}$ Aerospace Information Research Institute, Chinese Academy of Sciences, Beijing, China \\ ${ }^{2}$ Institute of Atmospheric Physics, Chinese Academy of Sciences, Beijing, China \\ ${ }^{3}$ Laboratoire d'Optique Atmosphérique, Université de Lille 1/CNRS, Lille, France \\ ${ }^{4}$ Department of Chemical and Biochemical Engineering, University of Iowa, Iowa City, IA, USA \\ ${ }^{5}$ Leipzig Institute for Meteorology, University of Leipzig, Leipzig, Germany
}

Correspondence: Zhengqiang Li (lizq@aircas.ac.cn)

Received: 21 January 2020 - Discussion started: 17 February 2020

Revised: 17 July 2020 - Accepted: 27 July 2020 - Published: 18 September 2020

\begin{abstract}
The Taklimakan Desert is a main and continuous source of Asian dust particles causing significant direct radiative effects, which are commonly quantified by the aerosol solar radiative forcing (ASRF). To improve the accuracy of estimates of dust ASRF, the Dust Aerosol ObservationKashi (DAO-K) campaign was carried out near the Taklimakan Desert in April 2019. The objective of the DAO-K campaign is to provide crucial parameters needed for the calculation of ASRF, such as dust optical and microphysical properties, vertical distribution, and surface albedo. The ASRF was calculated using radiative transfer (RT) simulations based on the observed aerosol parameters, additionally considering the measured atmospheric profiles and diurnal variations of surface albedo. As a result, daily average values of ASRF of $-19 \mathrm{~W} \mathrm{~m}^{-2}$ at the top of the atmosphere and $-36 \mathrm{~W} \mathrm{~m}^{-2}$ at the bottom of the atmosphere were derived from the simulations conducted during the DAO-K campaign. Furthermore, the Weather Research and Forecasting model with Chemistry (WRF-Chem), with assimilation of measurements of the aerosol optical depth and particulate matter (PM) mass concentrations of particles with aerodynamic diameter smaller than $2.5 \mu \mathrm{m}\left(\mathrm{PM}_{2.5}\right)$ and $10 \mu \mathrm{m}$ $\left(\mathrm{PM}_{10}\right)$, is employed to estimate the dust ASRF for comparison. The results of the ASRF simulations (RT and WRFChem) were evaluated using ground-based downward solar irradiance measurements, which have confirmed that the RT
\end{abstract}

simulations are in good agreement with simultaneous observations, whereas the WRF-Chem estimations reveal obvious discrepancies with the solar irradiance measurements.

\section{Introduction}

Atmospheric aerosol particles play a vital role in regional and global climate changes, directly by modifying the radiative balance of the Earth-atmosphere system, and indirectly by altering cloud radiative properties, as well as cloud development and precipitation through acting as cloud condensation nuclei $(\mathrm{CCN})$ and/or ice-nucleating particles (INPs) (Twomey, 1977; IPCC, 2007; Lenoble et al., 2013; Werner et al., 2014). Mineral dust is the most abundant large aerosol type in the atmosphere (Ansmann et al., 2011), which has a tremendous impact on the radiation budget, not only through scattering process but also due to absorption of solar (0.3$5 \mu \mathrm{m}$ ), also called shortwave (SW), radiation (Otto et al., 2007; García et al., 2012; Valenzuela et al., 2012; Lenoble et al., 2013), with potential dynamic consequences (Wendisch et al., 2008; Li et al., 2017). Atmospheric dust particles may also alter the cloud properties by serving as $\mathrm{CCN}$, giant $\mathrm{CCN}$, and INPs (Yin et al., 2002; DeMott et al., 2003; van den Heever et al., 2006). Numerous efforts have been undertaken to investigate the solar radiative effects of mineral dust us- 
ing radiative transfer (RT) models (e.g., Santa Barbara DISORT Atmospheric Radiative Transfer (SBDART), Fu-Liou RT model), or regional and global meteorological and climate models (e.g., Weather Research and Forecasting model with Chemistry (WRF-Chem), Regional Climate Model version 4 (RegCM4)) employing in situ and remote sensing observations in the simulations (Huang et al., 2009, 2014; Sun et al., 2012; Chen et al., 2013, 2014, 2018; Li et al., 2018). However, the quantification of the dust radiative effects is still challenging due to the high aerosol variability in space and time, and the complex light scattering properties of mineral dust. Moreover, the dust radiative effects depend on the surface albedo over the desert and the cloud layer in the vertical as well (Bierwirth et al., 2009; Waquet et al., 2013; Xu et al., 2017).

As one of the largest sandy deserts in the world, the Taklimakan Desert located in the Xinjiang Uygur Autonomous Region of China is a main source region of Asian dust (Huang et al., 2009). It influences not only surrounding areas such as the Tibetan Plateau (Liu et al., 2008; Chen et al., 2013; Yuan et al., 2019) but also wide regions in eastern Asia (Mikami et al., 2006; Liu et al., 2011a; Yuan et al., 2019) and even North America and Greenland through long-range transport across the Pacific Ocean (Bory et al., 2003; Chen et al., 2017; Liu et al., 2019). Therefore, an accurate assessment of the Taklimakan aerosol solar radiative forcing (ASRF, defined as the difference of the net solar irradiances with and without aerosols present) is important to evaluate regional and global climate changes. However, the results of corresponding simulations of ASRF applying different models with variable observation inputs vary widely in the open literature. Huang et al. (2009) employed the FuLiou RT model to simulate the Taklimakan ASRF during the dust episodes in the summer of 2006, and reported that the dust particles result in average daily mean solar warming effect of $14 \mathrm{~W} \mathrm{~m}^{-2}$ at the top of the atmosphere (TOA), atmospheric warming effect of $79 \mathrm{~W} \mathrm{~m}^{-2}$, and a surface cooling effect of $-65 \mathrm{~W} \mathrm{~m}^{-2}$. Sun et al. (2012) adopted the RegCM4 simulations and reported both negative values of the ASRF (i.e., cooling effects) of dust particles at the TOA and bottom of the atmosphere (BOA) with the strongest values (up to -4 and $-25 \mathrm{~W} \mathrm{~m}^{-2}$, respectively) in spring between 2000 and 2009 in the Taklimakan Desert region. Li et al. (2018) reported negative multi-year average values of the aerosol solar radiative forcing of $-16 \mathrm{~W} \mathrm{~m}^{-2}$ at the TOA and $-18 \mathrm{~W} \mathrm{~m}^{-2}$ at the BOA at the edge of the Taklimakan Desert, Kashi station, based on the SBDART simulations. The simulated results of dust aerosol radiative forcing have rarely been confirmed, especially in the Taklimakan Desert (Xia et al., 2009). Occasionally, the performance of various model-based ASRF estimates was evaluated against the observations of aerosol optical depth (AOD), aerosol extinction profile, single scattering albedo (SSA), and particle size distribution (Zhao et al., 2010; Chen et al., 2014). Nevertheless, comparison of ir- radiance is indispensable to provide direct evidence for corroborating the ASRF simulated results.

The knowledge of the optical, physical, chemical, and radiative properties of dust aerosol particles is crucial to derive the ASRF of dust particles. To precisely measure these important dust properties over the Taklimakan Desert, an intensive field campaign named Dust Aerosol ObservationKashi (DAO-K) was performed. One of the goals of the DAO-K field campaign is to provide high-quality dataset on aerosol in this region to obtain accurate assessment of the Taklimakan ASRF. In this paper, we focus on estimating direct ASRF of the dust-dominated aerosol population using SBDART simulations with appropriate ground-based and satellite measurements of aerosol parameters, surface albedo, and atmospheric vertical profiles. The ASRF simulations are comprehensively evaluated by comparison with the results of WRF-Chem simulations, ground-based irradiance measurements, as well as the AErosol RObotic NETwork (AERONET; http://aeronet.gsfc.nasa.gov, last access: July 2019) operational products (Holben et al., 1998).

Section 2 includes a brief introduction of the DAO-K field campaign and an overview of the multi-source observations and data. Methods for estimating ASRF by improving the inputs of atmospheric profiles and land surface albedo in the RT simulation, and by employing data assimilation in the WRF-Chem simulation, are described in Sect. 3. Section 4 presents the results of ASRF simulated by the RT model during the field campaign and for some specific cases. The influence of the atmosphere and surface conditions on the results is discussed. The differences from the corresponding AERONET operational products are also analyzed in this section. The comparison between the RT and WRF-Chem model simulations is discussed in Sect. 5. Both of the model simulations are evaluated based on the simultaneous irradiance measurements. A summary and conclusions are given in Sect. 6.

\section{Dust Aerosol Observation-Kashi field campaign}

\subsection{Observation site}

The DAO-K field campaign with comprehensive observations of physical, chemical, and optical properties of aerosol particles, solar radiation, vertical structures of the atmosphere, and land surface albedo in the Taklimakan Desert region was designed to provide high-quality data for aerosol radiative forcing estimates. Kashi is located at the edge of the Taklimakan Desert; it is surrounded by the Tianshan Mountains in the north, the Pamir plateau in the west, and the Kunlun Mountains in the south (Fig. 1). The DAO-K field campaign was conducted at the Kashi campus of the Aerospace Information Research Institute, Chinese Academy of Sciences $\left(39.50^{\circ} \mathrm{N}, 75.93^{\circ} \mathrm{E} ; 1320 \mathrm{~m}\right.$ above mean sea level). The campus hosts a long-term observation station within the 
Sun-sky radiometer Observation NETwork (SONET; http: //www.sonet.ac.cn/index.php, last access: July 2019) (Li et al., 2018). In addition to the Kashi station near the Taklimakan Desert, SONET also maintains two dust aerosol observation stations (i.e., Zhangye and Minqin stations) in the Gobi Desert, which is another important source of Asian dust. Although some studies reported that the dust generated in Taklimakan Desert exerts less influence on long-range downstream regions due to the unique terrain and low-level background wind climatology compared to those in Gobi Desert (Chen et al., 2017; Liu et al., 2019), the Taklimakan Desert is a better representative for studying the effects of dust aerosol solar radiative forcing on local regions rather than the Gobi Desert because of its huge dust emission capability (Chen et al., 2017).

Kashi represents a place heavily affected by dust aerosol particles. It is influenced by local anthropogenic pollution and pollution transported from surrounding arid and desert areas. According to the SONET long-term measurements from 2013, the Kashi site is frequently affected by dust, where the multi-year average AOD is up to $0.56 \pm 0.18$ at $500 \mathrm{~nm}$. Moreover, the Angström exponent (AE; 440$870 \mathrm{~nm}$ ) and fine-mode fraction (FMF; $500 \mathrm{~nm}$ ) at Kashi are the lowest (with the multi-year average values of $0.54 \pm 0.27$ and $0.40 \pm 0.14$, respectively; low values of $\mathrm{AE}$ indicate the presence of large dust particles) among all 16 sites within SONET around China ( $\mathrm{Li}$ et al., 2018). In contrast, the multiyear average AODs $(500 \mathrm{~nm})$ at Zhangye $(0.28 \pm 0.11)$ and Minqin $(0.26 \pm 0.11)$ are only half of that at Kashi or less; meanwhile, their average values of $\mathrm{AE}$ and FMF are also greater than those at Kashi (Li et al., 2018). These data imply that coarse particles are more dominant in the Taklimakan Desert in comparison to the Gobi Desert. Every year, FMF reaches the lowest value, and the volume particle size distribution presents a predominant coarse mode from March to May at Kashi (Li et al., 2018), due to the frequent dust invasions in spring. Chen et al. (2014) also reported that the dust radiative forcing had relatively small interannual variation but a distinct seasonal course with maximum values in late spring and early summer during the period of 2007 to 2011 in the Taklimakan Desert. Sun et al. (2012) found that the solar radiative heating peaks appear in April in southern Xinjiang and in May for northern Xinjiang. Thus, the DAO$\mathrm{K}$ intensive field campaign was carried out in April 2019 and lasted for nearly a month. During the campaign, several dust events were observed on the base of a coordinated deployment of multiple in situ and remote sensing platforms and state-of-the-art instruments based on passive and active detection technologies.

\subsection{Instrumentation}

Columnar aerosol properties are essential parameters for quantifying radiative forcing of atmospheric aerosol particles. However, high loading and complex light scatter-

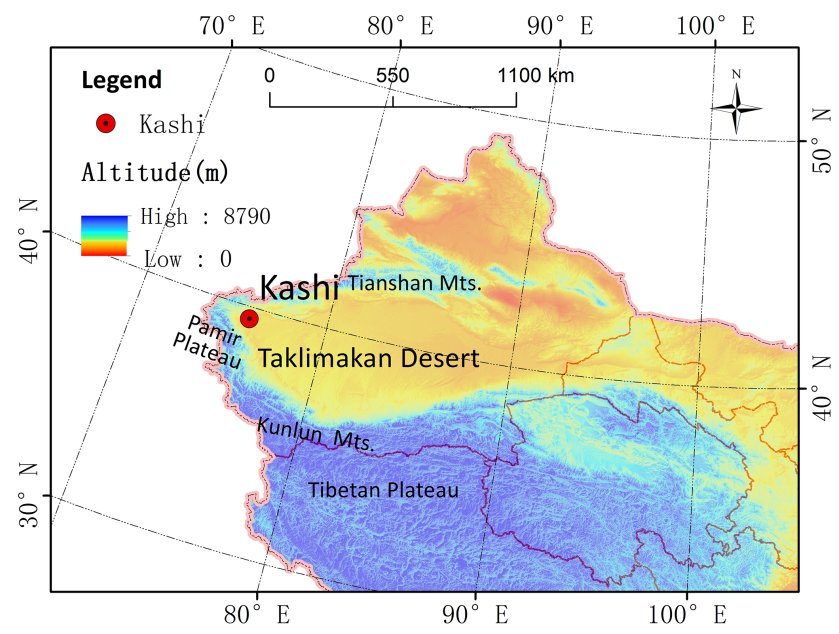

Figure 1. The location of the observation site (Kashi) of the DAO-K field campaign.

ing processes corresponding to diverse particle shapes bring challenges to remote sensing of mineral dust in the atmosphere (Dubovik et al., 2006; Bi et al., 2010; Li et al., 2019). Ground-based detection by Sun-sky radiometer works out a solution by modeling dust particles as randomly oriented spheroids in the retrieval framework (Dubovik et al., 2006). From these activities, quality-assured databases of dust aerosol properties became available based on both the AERONET and SONET Sun-sky radiometer retrievals (Holben et al. 1998; Li et al., 2018). During the DAO-K campaign, four Cimel Sun-sky radiometers, including a polarized Sun-sky-Moon radiometer CE318TP (no. 1150), two unpolarized Sun-sky-Moon radiometers CE318-T (nos. 1098 and 1141), and a polarized Sunsky radiometer CE318-DP (no. 0971), were deployed at Kashi (Fig. 2a). CE318 nos. 1150 and 1141 were calibrated rigorously at the AERONET Izaña Observatory with the accuracy of AOD about $0.25 \%-0.5 \%$, while AOD-related measurements and sky radiance measurements of CE318 nos. 1098 and 0971 were calibrated via the master instrument (no. 1150) by a vicarious/transfer calibration method before the field campaign (Holben et al., 1998; Li et al., 2008, 2018). The volume aerosol parameters of AOD, SSA, $\mathrm{AE}$, and asymmetry factor (i.e., $g$ ) in four channels with center wavelengths of 440, 675, 870, and $1020 \mathrm{~nm}$ were retrieved following the SONET level-1.5 data criteria (Li et al., 2018). Observations from the CE318 no. 1141 also joined in the AERONET dataset. The consistency of the products following the AERONET and SONET retrieval frameworks has been validated by $\mathrm{Li}$ et al. (2018). The multiwavelength properties of AOD, SSA, AE, and $g$ were applied in RT simulations. In addition to Sun-sky radiometers, a METONE BAM-1020 continuous particulate monitor was also deployed to measure $\mathrm{PM}_{2.5}$ mass concentration $\left(\mathrm{mg} \mathrm{m}^{-3}\right.$ ) (Fig. 2a). The hourly $\mathrm{PM}_{10}$ mass concentrations 


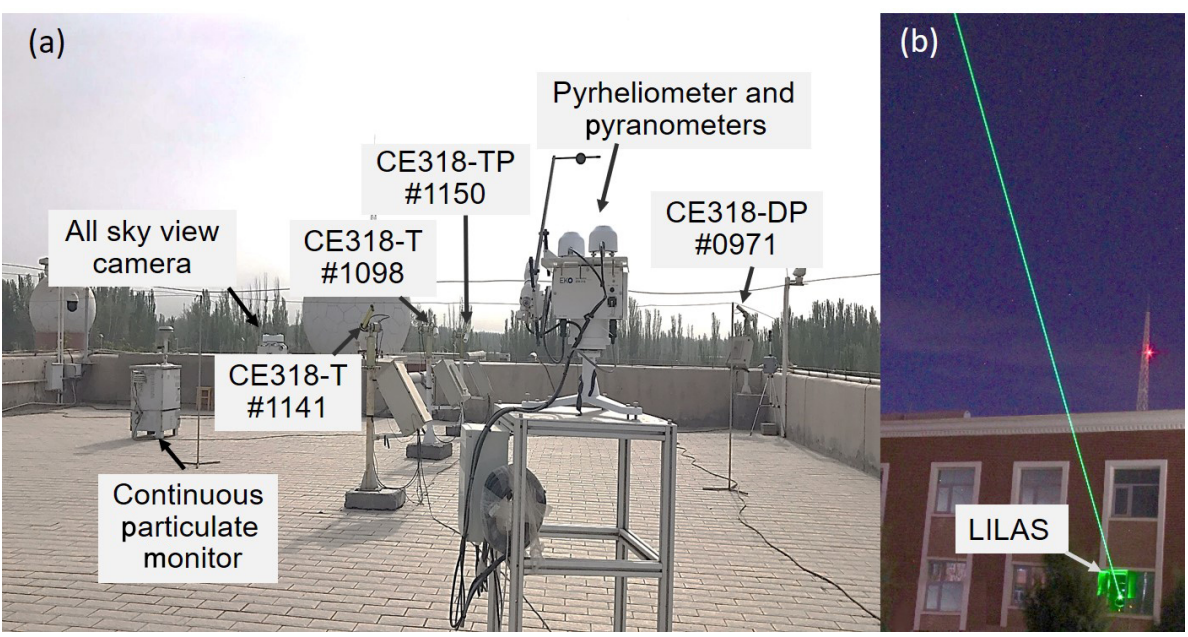

Figure 2. Setup of experimental apparatus of the DAO-K field campaign (a) on the roof and (b) indoors.

( $\mathrm{mg} \mathrm{m}^{-3}$ ) were collected from the routine measurements of the ambient air quality continuous automated monitoring system in Kashi operated by the China National Environmental Monitoring Center. The aerosol parameters including AOD, $\mathrm{PM}_{2.5}$, and $\mathrm{PM}_{10}$ mass concentrations were assimilated in the WRF-Chem model simulation in this study.

Aerosol radiative effects also depend on the surface albedo and the vertical structure of atmosphere (Wendisch et al., 2004). During the DAO-K campaign, atmospheric profiles, including the vertical distributions of the atmospheric pressure, temperature, and relative humidity, were collected from sounding balloon measurements. The sounding balloons were operationally launched twice a day around 00:00 and 12:00 UTC at the Kashi weather station $\left(39.46^{\circ} \mathrm{N}, 75.98^{\circ} \mathrm{E}\right.$; $1291 \mathrm{~m}$ above mean sea level). Normally, about 3000 individual measurements are recorded during one balloon flight, which corresponds to a sampling frequency of $1 \mathrm{~s}$ (Guo et al., 2016; Chen et al., 2019). The data quality was controlled following the operational specifications for conventional upperair meteorological observations (China Meteorological Administration, 2010). The accuracy of the temperature profile in the troposphere is within $\pm 0.1 \mathrm{~K}$ (Zhang et al., 2018; Guo et al, 2019). In addition to pressure, temperature, and relative humidity profiles, ozone profiles obtained by the Ozone Monitoring Instrument (OMI)/Aura satellite (Bhartia et al., 1996) were used as input for the RT model. The satellite observations of the Moderate Resolution Imaging Spectroradiometer (MODIS) aboard Terra and Aqua were employed to collect the surface reflection during the DAO-K campaign. The MODIS products of shortwave bidirectional reflectance distribution function (BRDF) parameters, black-sky albedo (BSA), and white-sky albedo (WSA) were adopted to derive the surface albedo during daytime (Schaaf and Wang, 2015). A solar radiation monitoring station, equipped with an EKO MS-57 pyrheliometer and two MS-80 pyranometers, was used for measuring the direct, diffuse, and total solar ir- radiances $\left(\mathrm{W} \mathrm{m}^{-2}\right)$ in the range of $0.28-3.0 \mu \mathrm{m}$ (Fig. 2a). The pyrheliometer and pyranometers have been calibrated before the campaign with uncertainties of $0.55 \%$ and $0.66 \%$, respectively. They satisfy the requirements of class A under ISO 9060:2018 with response time of less than 0.2 and $0.4 \mathrm{~s}$, separately. The fraction of diffuse skylight radiation deduced from the diffuse and total irradiances also gave a key weighting index to modulate the diurnal changes of the surface albedo.

Further instruments provided independent evidence of the existence of dust and cloud layers during the observations. Multi-wavelength Mie-Raman polarization lidar (LILAS) developed by the Laboratoire d'Optique Atmosphérique, Université de Lille 1 (Fig. 2b), was equipped with three elastic wavelengths (all linearly polarized) at 355,532 , and $1064 \mathrm{~nm}$, and three Raman wavelengths at 387, 530, and $408 \mathrm{~nm}$, from which the vertical distribution of multiple optical and physical properties of dust aerosol particles can be obtained (Veselovskii et al., 2016, 2018; Hu et al., 2019). The backscattering coefficient profile at $355 \mathrm{~nm}$ wavelength was applied in this study to distinguish the two-layer structure of dust. The YNT all-sky view camera ASC200 equipped with two wide-dynamic full-sky visible and infrared imagers, recorded dynamic states of clouds during day and night with $10 \mathrm{~min}$ (or less than $10 \mathrm{~min}$ ) resolution. An overview of the instruments and corresponding parameters employed in the study is listed in Table 1. Considering different durations of various measurements, we calculated and discussed the ASRF from 2 to 25 April 2019, when simultaneous measurements are available. 
Table 1. Overview of the parameters and instruments employed in the radiative transfer and WRF-Chem model simulations and validation.

\begin{tabular}{|c|c|c|c|}
\hline Application & Parameter & Instrument & Time period of operation \\
\hline \multirow{8}{*}{$\begin{array}{l}\text { Radiative } \\
\text { transfer } \\
\text { simulation }\end{array}$} & \multicolumn{3}{|l|}{ Aerosol properties } \\
\hline & $\begin{array}{l}\text { Aerosol optical depth } \\
\text { Ångström exponent } \\
\text { Single scattering albedo } \\
\text { Asymmetry factor }\end{array}$ & Sun-sky radiometer & 1-25 April 2019 \\
\hline & \multicolumn{3}{|l|}{ Atmospheric profiles } \\
\hline & $\begin{array}{l}\text { Vertical distributions of } \\
\text { atmospheric pressure, } \\
\text { temperature, } \\
\text { relative humidity }\end{array}$ & Sounding balloon & 1-30 April 2019 \\
\hline & Ozone profile & OMI/Aura & 1-30 April 2019 \\
\hline & \multicolumn{3}{|l|}{ Land surface albedo } \\
\hline & $\begin{array}{l}\text { Shortwave BRDF parameters } \\
\text { Shortwave black-sky albedo } \\
\text { Shortwave white-sky albedo }\end{array}$ & MODIS Terra and Aqua & 1-30 April 2019 \\
\hline & $\begin{array}{l}\text { Diffuse solar irradiance } \\
\text { Total solar irradiance }\end{array}$ & Pyranometers & 2-28 April 2019 \\
\hline \multirow{3}{*}{$\begin{array}{l}\text { WRF-Chem } \\
\text { simulation }\end{array}$} & Aerosol optical depth & Sun-sky radiometer & 1-25 April 2019 \\
\hline & $\mathrm{PM}_{2.5}$ mass concentration & Continuous particulate monitor & 1-28 April 2019 \\
\hline & $\mathrm{PM}_{10}$ mass concentration & $\begin{array}{l}\text { Ambient air quality continuous } \\
\text { automated monitoring system }\end{array}$ & 1-30 April 2019 \\
\hline \multirow[t]{3}{*}{$\begin{array}{l}\text { Evidence and } \\
\text { validation }\end{array}$} & $\begin{array}{l}\text { Direct normal solar irradiance } \\
\text { Diffuse solar irradiance } \\
\text { Total solar irradiance }\end{array}$ & $\begin{array}{l}\text { Pyrheliometer } \\
\text { Pyranometers }\end{array}$ & 2-28 April 2019 \\
\hline & Backscattering coefficient & LILAS & 4-28 April 2019 \\
\hline & Full-sky visible image & All-sky view camera & 2-27 April 2019 \\
\hline
\end{tabular}

\section{Estimation of aerosol solar radiative forcing}

\subsection{Definition of aerosol solar radiative forcing}

The direct solar radiative forcing of atmospheric aerosol particles is calculated using the following equations (Babu et al., 2002; Adesina et al., 2014; Esteve et al., 2014):

$\mathrm{ASRF}_{\mathrm{TOA}}=F_{\text {net,TOA }}^{\mathrm{a}}-F_{\text {net,TOA }}^{0}$,

$\mathrm{ASRF}_{\mathrm{BOA}}=F_{\text {net,BOA }}^{\mathrm{a}}-F_{\text {net,BOA }}^{0}$,

$\mathrm{ASRF}_{\mathrm{ATM}}=\mathrm{ASRF}_{\mathrm{TOA}}-\mathrm{ASRF}_{\mathrm{BOA}}$,

$F_{\text {net }}=F^{\downarrow}-F^{\uparrow}$,

where $\mathrm{ASRF}_{\mathrm{TOA}}, \mathrm{ASRF}_{\mathrm{BOA}}$, and $\mathrm{ASRF}_{\mathrm{ATM}}$ denote the direct aerosol solar radiative forcing at the TOA, BOA, and in the atmosphere (ATM), respectively. $F_{\text {net }}^{\mathrm{a}}$ and $F_{\text {net }}^{0}$ indicate the net irradiances with and without aerosols, respectively. $F^{\downarrow}$ and $F^{\uparrow}$ separately represent the downward and upward irradiances. All the above quantities are measured in physical units of $\mathrm{W} \mathrm{m}^{-2}$. The radiative forcing efficiency is defined as the rate at which the atmosphere is forced per unit of aerosol optical depth at $550 \mathrm{~nm}$ (García et al., 2008, 2012):

$\mathrm{ASRFE}=\mathrm{ASRF} / \tau_{550}$,

where ASRFE (in $\mathrm{W} \mathrm{m}^{-2} \tau_{550}^{-1}$ ) is the aerosol solar radiative forcing efficiency at the TOA, BOA, or in ATM. Since the effects of aerosol loading on radiative forcing have been eliminated, radiative forcing efficiency has unique advantage on evaluation of the direct radiative effects of different types of aerosols (García et al., 2008).

\subsection{Radiative transfer simulations}

The focus of this study is to quantify the direct ASRF and ASRFE at the TOA, BOA, and in ATM under cloud-free conditions using the SBDART model fed with comprehensive ground-based and satellite observations collected during the DAO-K campaign. SBDART is a radiative transfer software 
tool that has been widely applied in atmospheric radiative energy balance studies (Ricchiazzi et al., 1998; Li et al., 2018). The discrete ordinate method is adopted in the code, which provides a numerically stable algorithm to solve the equations of plane-parallel radiative transfer in a vertically inhomogeneous atmosphere (Ricchiazzi et al.,1998). The simulations cover the same wavelength range (i.e., $0.28-3.0 \mu \mathrm{m}$ ) as the pyranometer for convenience of comparison. Simulations of the ASRF by the SBDART model are susceptible to the input conditions including the aerosol properties, atmosphere profiles, and land surface albedo. These input data were specified based on the high-quality dataset obtained in the DAO-K campaign.

\subsubsection{Aerosol properties}

The aerosol properties including AOD, SSA, AE, and $g$ were retrieved from the radiometer observations at four bands with the central wavelengths at 440, 675, 870, and $1020 \mathrm{~nm}$. They were applied in the instantaneous radiative forcing and efficiency calculations at the corresponding observing time. The aerosol properties in the SW range are obtained by interpolation and extrapolation using parameters in the abovementioned four wavelength bands. For daily mean ASRF simulation, the averaged aerosol parameters (i.e., AOD, SSA, AE, and $g$ ) obtained from the daytime radiometer observations were used as alternatives of the daily mean aerosol properties. The daily mean aerosol radiative forcing and efficiency were calculated by taking the average of the 24 instantaneous values on an hourly basis.

\subsubsection{Atmospheric profiles}

In addition to aerosol properties, atmospheric profiles of thermodynamic properties are important for the ASRF calculations. The vertical distributions of air pressure, temperature, water vapor, and ozone densities exert obvious influence on the direct and diffuse solar irradiances at the BOA. The predefined atmospheric profiles in the used RT model (e.g., tropical, midlatitude summer, midlatitude winter, sub-arctic summer, sub-arctic winter profiles) are different from Kashi local conditions. Therefore, within the ASRF simulations, the pre-defined profiles have been replaced by the actual measurements conducted during the DAO-K campaign. Vertical distributions of the atmospheric pressure, temperature, and relative humidity can be obtained by atmospheric sounding twice a day around 00:00 and 12:00 UTC at Kashi. The profiles of ozone density (in $\mathrm{g} \mathrm{m}^{-3}$ ) were deduced from the OMI/Aura OMO3PR product (in Dobson units; DU) (Bhartia et al., 1996). Two atmospheric profiles were specified for each day. The profile closest to the ASRF simulated moment was adopted for both of instantaneous and daily mean aerosol radiative forcing estimates.

\subsubsection{Surface albedo}

Land surface albedo (LSA) is another key factor to influence the radiation budget, mainly due to its significant impact on the SW upward irradiance (Liang, 2004; Wendisch et al., 2004; Bierwirth et al., 2009; Tegen et al., 2009; Jäkel et al., 2013; Stapf et al., 2019). Shortwave land surface albedo $\alpha_{\mathrm{SW}}$, also known as blue-sky albedo, can be calculated from the black-sky albedo $\alpha_{\mathrm{SW}}^{\mathrm{BSA}}$ and white-sky albedo $\alpha_{\mathrm{SW}}^{\mathrm{WSA}}$ weighted by the fraction of diffuse skylight radiation (Schaaf et al., 2002; Wang et al., 2015):

$$
\begin{aligned}
\alpha_{\mathrm{SW}}\left(\theta_{\mathrm{s}}, \varphi_{\mathrm{s}}\right)= & f_{\text {diffuse, } \mathrm{SW}} \alpha_{\mathrm{SW}}^{\mathrm{WSA}}+\left(1-f_{\text {diffuse }, \mathrm{SW}}\right) \\
& \alpha_{\mathrm{SW}}^{\mathrm{BSA}}\left(\theta_{\mathrm{s}}, \varphi_{\mathrm{s}}\right),
\end{aligned}
$$

where $f_{\text {diffuse, Sw }}$ denotes the fraction of diffuse radiation in the solar spectral range. $\left(\theta_{\mathrm{s}}, \varphi_{\mathrm{s}}\right)$ specifies the incident solar geometry (i.e., solar zenith angle and solar azimuthal angle).

The shortwave WSA and BSA are provided by the MODIS BRDF/albedo science data product MCD43A3, which is produced daily using $16 \mathrm{~d}$ of MODIS Terra and Aqua data. MCD43A3 only delivers the surface albedo products at local solar noon. However, diurnal variations of LSA cannot be ignored, which has been demonstrated by previous studies (Lewis and Barnsley, 1994; Lucht et al., 2000; Wang et al., 2015). There will be an obvious bias in estimating daily solar radiation when simply using the local noon value as a surrogate of daily mean albedo (Wang et al., 2015). As for the weighting parameters of the RossThickLiSparseReciprocal BRDF model (i.e., isotropic, volumetric, and geometric), the changes within $16 \mathrm{~d}$ are subtle. Therefore, the daily three model weighting parameters over the SW band afforded by the MODIS product MCD43A1 are adopted to derived the WSA and BSA (the latter is as a function of incident solar direction) at different ASRF simulated moments. The fraction of diffuse radiation can be calculated by the ratio of diffuse solar irradiance to total solar irradiance, which mainly depends on the solar zenith angle, aerosol, and cloud conditions. The diffuse and total irradiances measured by pyranometers with $1 \mathrm{~min}$ resolution are applied in this study to calculate the fraction of diffuse radiation.

Figure 3 illustrates the diurnal variations of LSA and corresponding full-sky visible images under four typical sky conditions at Kashi. For the cloud-free and low aerosol loading conditions (identified as clear sky, e.g., almost the whole day of 7 April 2019 and afternoon of 12 April 2019), LSA changes distinctively for different time. High values of LSA are observed in the early morning and the late afternoon. Meanwhile, the extreme value of LSA in the morning (0.253) is greater than that in the afternoon $(0.218)$, which has been supported by some other field observations (Minnis et al., 1997; Wang et al., 2015). The local noon albedo shows a very low value. The daily mean albedo under the clear-sky condition (0.199) is significantly greater than the local noon albedo (0.173). However, in dust-polluted (almost the whole 

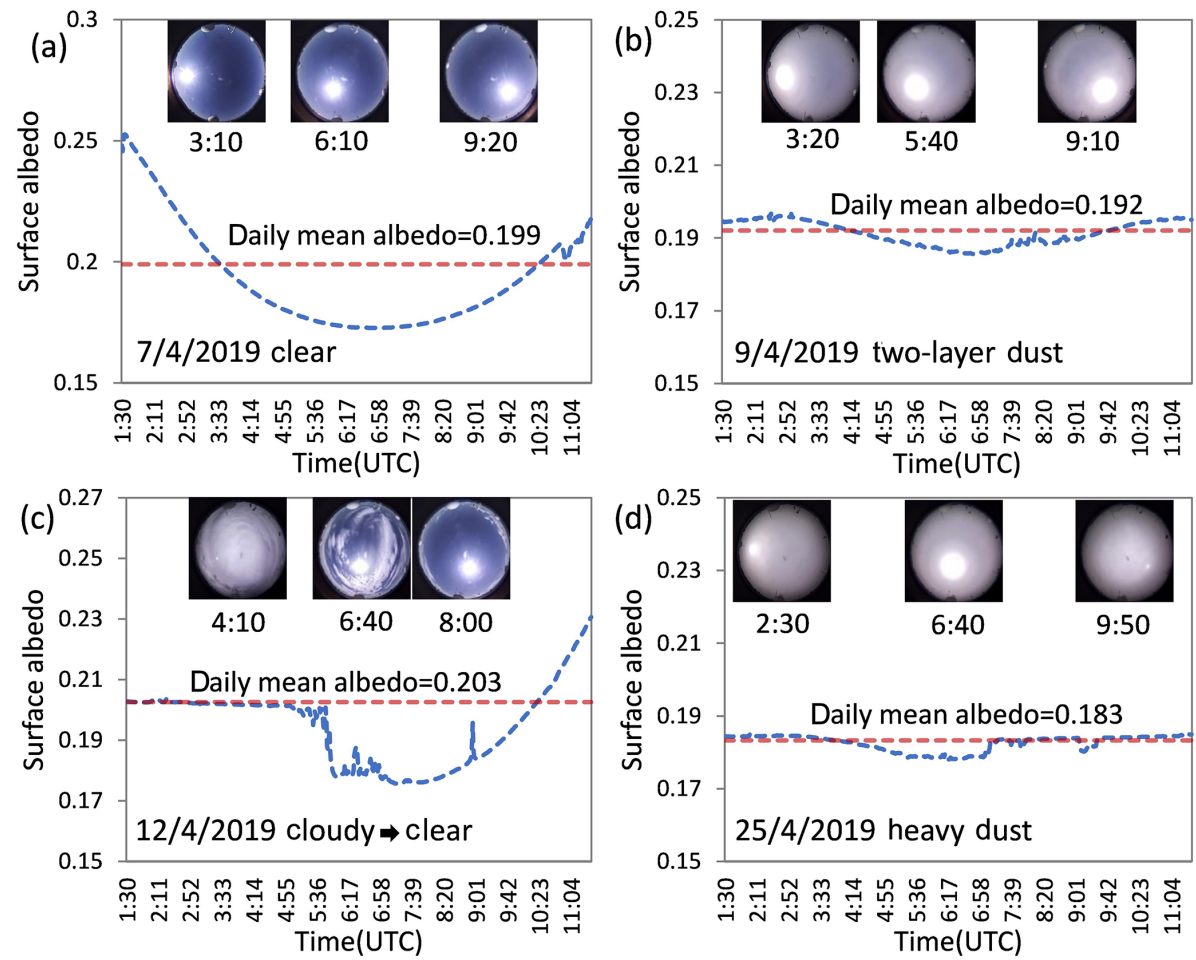

Figure 3. Diurnal variations of blue-sky albedo and corresponding full-sky visible images under different sky conditions at Kashi: (a) clear case, (b) two-layer dust case, (c) clouds early/clearing late case, and (d) heavy dust case.

days of 9 and 25 April 2019) and cloudy (the morning of 12 April 2019) sky conditions, the changes of LSA are not as severe as in the clear-sky conditions. Nevertheless, the local noon albedo still cannot reflect the effects of aerosol and cloud variations on land surface albedo. Thus, diurnalchanged LSA and the daily mean albedo were adopted in the instantaneous and daily mean ASRF simulations, respectively. It is expected that estimations of instantaneous and daily mean aerosol radiative forcing can be improved by considering diurnal variations of LSA instead of local noon albedo.

\subsection{WRF-Chem simulations}

\subsubsection{Forecast model}

WRF-Chem version 4.0 (Grell et al., 2005; Fast et al., 2006) was used to simulate the ASRF at Kashi. The simulations were configured in a $9 \mathrm{~km}$ domain centered at the Kashi site with $45 \times 45$ grid points and 41 vertical levels that extended from the surface to $50 \mathrm{hPa}$. The main physical options used for this study included the Purdue-Lin microphysics scheme, the unified Noah land surface model, the Yonsei University (YSU) scheme for planetary boundary layer meteorological conditions, and the Rapid Radiative Transfer Model for General Circulation Models (RRTMG) for solar and terrestrial radiation (Lin et al., 1983; Mlawer et al., 1997; Chen and Dud- hia, 2001; Hong et al., 2006; Iacono et al., 2008). The Carbon Bond Mechanism (CBMZ) was used for the gas-phase chemistry processes (Zaveri and Peters, 1999), which included aqueous-phase chemistry. The aerosol chemistry was based on the Model for Simulating Aerosol Interactions and Chemistry (MOSAIC; Zaveri et al., 2008) with four size bins (0.039-0.156, 0.156-0.625, 0.625-2.5, and 5.0-10.0 $\mu \mathrm{m}$ dry diameters). The sum of aerosol mass concentrations in the first three size bins constructs the concentration of $\mathrm{PM}_{2.5}$ and the sum of the four size bins gives the concentration of $\mathrm{PM}_{10}$. Aerosol types such as sulfate, methanesulfonate, nitrate, ammonium, black carbon, primary organic carbon, sodium, calcium, chloride, carbonate, aerosol liquid water, and other inorganic matter (e.g., trace metals and silica) are involved in the simulation. Dust was simulated with the Goddard Chemistry Aerosol Radiation and Transport (GOCART) dust emission scheme (Ginoux et al., 2001). The dust particulates were aggregated into the other inorganic matter component and were presented in the calculation of aerosol optical properties with anthropogenic aerosols.

Aerosol particle optical properties were calculated as a function of wavelength based on the Mie theory. The aerosol components within each size bin are assumed to be internally mixed. The mixing refractive indices are the volumeweight average in refractive indices of all aerosol components. Aerosol extinction and scattering coefficients and the asymmetry factor for a particulate per size bin are attained 
though searching a look-up Mie table by Chebyshev polynomial interpolation with the desired mixing refractive indices and wet particulate radius. The value of particulate extinction coefficient multiplied with the particulate number concentration is volume extinction coefficient which is then multiplied with the height of layer to attain the layer AOD value. The sum of all layer AOD values over the four size bins is the columnar total AOD and is used for calculating AOD increments in the assimilation.

\subsubsection{Assimilation system}

The Gridpoint Statistical Interpolation (GSI) 3D-Var assimilation system version 3.7 was applied to improve the simulated aerosols by assimilating the aerosol measurements collected at Kashi during the DAO-K campaign (Wu et al., 2002; Kleist et al., 2009). This GSI version has been modified to assimilate the aerosol products (Liu et al., 2011b; Schwartz et al., 2012). We assimilated our ground-based multi-wavelength AOD $(440,675,870,1020 \mathrm{~nm})$ and the surface-layer concentrations of $\mathrm{PM}_{2.5}$ and $\mathrm{PM}_{10}$ suited to the MOSAIC aerosol module in WRF-Chem. We used the natural logarithm of particulate number concentration per size bin as control variables. The aerosol dry mass concentrations, particulate number concentrations, and aerosol water content are converted into AOD per size bin using the WRF-Chem aerosol optical routine. The adjoint observation operators for $\mathrm{AOD}$ and particulate matter are given as

$$
\begin{aligned}
& \frac{\delta \ln (\tau)}{\delta \ln \left(n_{i}\right)}=\frac{n_{i}}{\tau} \cdot \frac{\delta \tau}{\delta n_{i}}=\frac{n_{i}}{\tau} \cdot e_{i}=\frac{\tau_{i}}{\tau}, \\
& \frac{\delta \ln (c)}{\delta \ln \left(n_{i}\right)}=\frac{n_{i}}{c} \cdot \frac{\delta c}{\delta n_{i}}=\frac{n_{i}}{c} \cdot r_{i},
\end{aligned}
$$

where $n_{i}$ is aerosol number concentration in the $i$ th size bin, $\tau$ and $c$ are the observed AOD and particulate matter mass concentrations. As no aerosol particle extinction coefficient assimilated in this experiment, we assume the extinction coefficient per size bin is constant in grid at each model layer. Innovation of number concentration due to AOD constraint is therefore a proportion of change in model layer AOD to the observed columnar AOD, which is attained via iteration to minimize the cost function. Innovation of number concentration due to the constraints of $\mathrm{PM}_{2.5}$ and $\mathrm{PM}_{10}$ is associated with the ratios $\left(r_{i}\right)$ of mass concentrations to number concentrations in a size bin estimated in the guess field, weighted by the proportion of the size number concentration, changing in the iteration, to the total particulate matter concentration.

\subsubsection{Model setup}

Initial and lateral boundary conditions for the meteorological fields in the WRF-Chem simulations were generated from the National Centers for Environmental Prediction (NCEP) Final Analysis (FNL) data using the Global Forecast System (GFS) model at a horizontal resolution of $1^{\circ}$. The boundary conditions were updated every $6 \mathrm{~h}$ and then interpolated linearly in time by WRF-Chem. Anthropogenic emissions from the 2010 MIX emission inventories (http://www.meicmodel. org/, last access: July 2019) containing the Multi-resolution Emission Inventory of China (MEIC) were used in the simulations. The biogenic emissions were estimated using the Model of Emissions of Gases and Aerosols from Nature (MEGAN; Guenther et al., 2006). Two 1-month WRF-Chem simulations were performed for April 2019, discarding a 1week spin-up at the beginning of each simulation. The first 1-month simulation was used for modeling background error covariance. The second 1-month simulation was assimilated the observations of $\mathrm{PM}_{2.5}, \mathrm{PM}_{10}$, and AOD with GSI at 00:00, 06:00, 12:00, and 18:00 UTC with the assimilation window of $\pm 3 \mathrm{~h}$ centered at the analysis time. The model was restarted from the meteorology and chemistry at analysis time and ran to the next analysis time. For the second one, each restart called the radiation routines twice which included and excluded the aerosols, respectively, and the corresponding difference between the two calls in irradiances is aerosol radiative forcing.

A general way to model background error covariance is the National Meteorological Center (NMC) method that computes the statistical differences between two forecasts with different leading lengths (e.g., 12 and $24 \mathrm{~h}$, or 24 and $48 \mathrm{~h}$ ) but valid at the same time (Parrish and Derber, 1992). However, in some experiments, the WRF-Chem model underestimated aerosol concentrations and hence likely lowered the error magnitudes. For this reason, we assessed the standard deviations of the control variables over the entire 1-month period at the four analysis hours (i.e., 00:00, 06:00, 12:00, and 18:00 UTC), respectively. Each standard deviation field was used for modeling a background error covariance repeatedly applied in the assimilation at the corresponding analysis hour. This approach represents the strong fluctuations of control variables as weather evolution during clear and dusty days. We expect fluctuations of aerosols over different weather are larger than the uncertainties due to different leading forecast lengths and may give a better input field for modeling background error covariance. The observation errors for AOD and PM were $50 \%$ of natural logarithm of 0.01 and those errors of PM including measurement error and representative error depending on the grid size and the PM concentrations (Schwartz et al., 2012). The choice of $50 \%$ was determined by trying experimentally with different values, which can effectively assimilate measurements and will not excessively damage the model results.

\section{Results of radiative transfer simulations}

\subsection{Aerosol solar radiative forcing and efficiency}

The time series of the measured values of AOD, AE, $\mathrm{PM}_{2.5}$, and $\mathrm{PM}_{10}$ mass concentrations collected during the DAO-K 


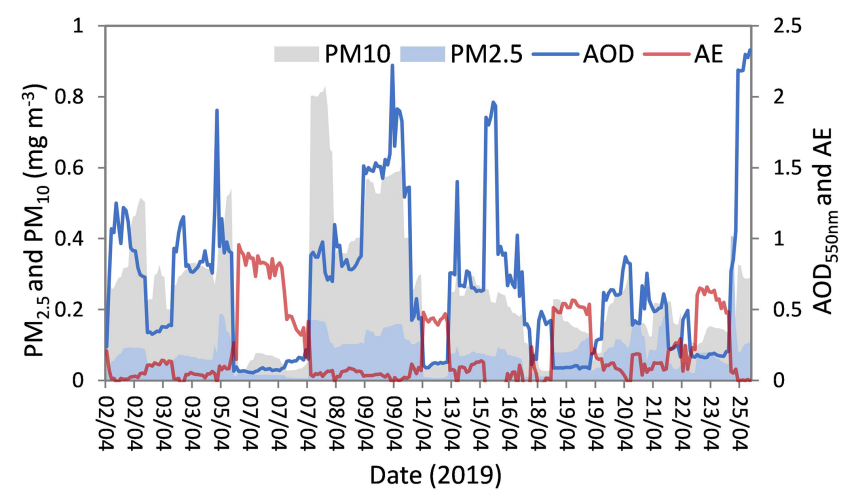

Figure 4. Variations of aerosol optical depth (550 nm), Ångström exponent (440-870 $\mathrm{nm}$ ), and $\mathrm{PM}_{2.5}$ and $\mathrm{PM}_{10}$ mass concentrations at the Kashi site during the DAO-K campaign.

campaign are shown in Fig. 4. The average value of AOD at $550 \mathrm{~nm}$ wavelength is 0.65 during the campaign. According to AOD, five high aerosol loading episodes are identified: 09:26-12:15 UTC on 2 April 2019, 09:13 on 3 April 2019 until 05:11 UTC on 5 April 2019, 01:52 on 8 April 2019 until 04:20 UTC on 10 April 2019, 01:47 on 13 April 2019 until 12:32 UTC on 16 April 2019, and 01:30 on 24 April 2019 until 04:11 UTC on 25 April 2019. The highest values of AOD at $550 \mathrm{~nm}$ (2.3) were observed from 24 to 25 April 2019 during a severe dust storm event. From Fig. 4, a negative correlation between $\mathrm{AOD}$ and $\mathrm{AE}$ becomes obvious. For the five high aerosol loading episodes, the AEs show very low values, suggesting that the heavy aerosol outbreaks at Kashi were dominated by dust particles. As a qualitative indicator of aerosol particle size, the values of AE are always less than 1.0 during the DAO-K campaign, illustrating the fact that aerosol particles around the Taklimakan Desert are mainly dominated by coarse particles (even for clear situations). This is consistent with the results obtained in a previous study (Fig. 4 in Li et al., 2018). Comparatively high values of AE (>0.4) are observed on 7, 12, 19, and 23 April 2019, implying relatively small particle enrichments for these days. The time series of $\mathrm{PM}_{2.5}$ and $\mathrm{PM}_{10}$ mass concentrations generally concur with that of AOD. However, for some days, such as 19 and 23 April 2019, relatively high $\mathrm{PM}_{2.5}$ corresponding to low AOD has been observed, indicating an enhanced influence of anthropogenic pollution. For the measurements on 7 and 12 April 2019, high AE values corresponding to low $\mathrm{PM}_{2.5}$ concentrations could be down to the very low turbidity conditions. It should be noted that the errors in computations of AE significantly increase under low aerosol loading conditions (Kaskaoutis et al., 2007).

Results of instantaneous ASRF and ASRFE during the DAO-K campaign are given in Fig. 5. Both positive and negative values of ASRF, corresponding to warming and cooling effects, respectively, can be found at top of the atmosphere (Fig. 5a). However, aerosols have only warming ef- fects in the atmosphere (Fig. 5c) and cooling effects at the surface (Fig. 5e) during the DAO-K campaign. ASRF values at the TOA and BOA exhibit obvious negative correlations with AOD. Positive correlations are observed between ASRF within the atmospheric column and AOD. From Fig. 5, it is evident that the dust aerosol has strong influence on the solar radiation budget. For the five high aerosol loading episodes (Fig. 4), the dust-dominant aerosol population exerts stronger cooling effects at the TOA and BOA, and more significant warming effects in the atmosphere than other low aerosol loading situations. Moreover, the cooling effects at the BOA are more noticeable than at the TOA, with minimum values around -217 and $-119 \mathrm{~W} \mathrm{~m}^{-2}$, respectively.

When ASRF is normalized by aerosol optical depth at $550 \mathrm{~nm}$ wavelength, the ASRFE is obtained. This quantity is mostly insensitive to the aerosol loading, at least if a linear relation between ASRF and AOD is assumed. Nevertheless, a weak negative correlation between ASRFE and AE can be observed at the BOA (Fig. 5f). That means the ASRFE at the surface can roughly indicate the radiative forcing effects of different types of aerosols (García et al., 2008). A relatively large fraction of small particles associated with high $\mathrm{AE}$ has stronger ASRFE for cooling the surface than other low AE situations. But for TOA and ATM (Fig. 5b, d), there is no obvious correlation between ASRFE and AE. Generally, the cooling effect of aerosols at Kashi is more efficient at the BOA than that at the TOA. It is in accordance with the results of ASRF. In comparison to ASRF, the variation of ASRFE is relatively moderate during the campaign. The strongest cooling effects on the TOA and BOA all appear in the episode of dust storm outbreak (i.e., 24 and 25 April 2019) (see Fig. 5a, e). But large dust particles in this case do not show extreme radiative forcing efficiency (Fig. 5b, f). Strong cooling efficiencies at the surface during the DAO-K campaign occur in the very clear cases with high AE on 7 April 2019 (Fig. 5f).

During the DAO-K campaign, the average values of daily mean ASRF at Kashi are $-19 \pm 13 \mathrm{~W} \mathrm{~m}^{-2}$ at the TOA and $36 \pm 23 \mathrm{~W} \mathrm{~m}^{-2}$ at the BOA, which are slightly stronger than the multi-year average values at this site (i.e., $-16 \mathrm{~W} \mathrm{~m}^{-2}$ at the TOA and $-18 \mathrm{~W} \mathrm{~m}^{-2}$ at the BOA) obtained by the previous study ( $\mathrm{Li}$ et al., 2018). These results are reasonable, since the campaign was performed in the dust-prone season and higher aerosol loading situations have stronger ASRF effects as discussed above. Likewise, the average values of daily mean ASRFE at the TOA and BOA during the DAO-K campaign are $-27 \pm 9 \mathrm{~W} \mathrm{~m}^{-2} \tau_{550}^{-1}$ and $-55 \pm 10 \mathrm{~W} \mathrm{~m}^{-2} \tau_{550}^{-1}$, respectively, which are more efficient than the corresponding multi-year average values (i.e., $-21 \mathrm{~W} \mathrm{~m}^{-2} \tau_{550}^{-1}$ at the TOA and $-24 \mathrm{~W} \mathrm{~m}^{-2} \tau_{550}^{-1}$ at the $\mathrm{BOA}$ ) reported in the previous study (Li et al., 2018).

\subsubsection{Clear-sky case}

Instantaneous ASRF and ASRFE of the clear-sky case on 7 April 2019 are depicted in Fig. 6. It was a typical cloud- 

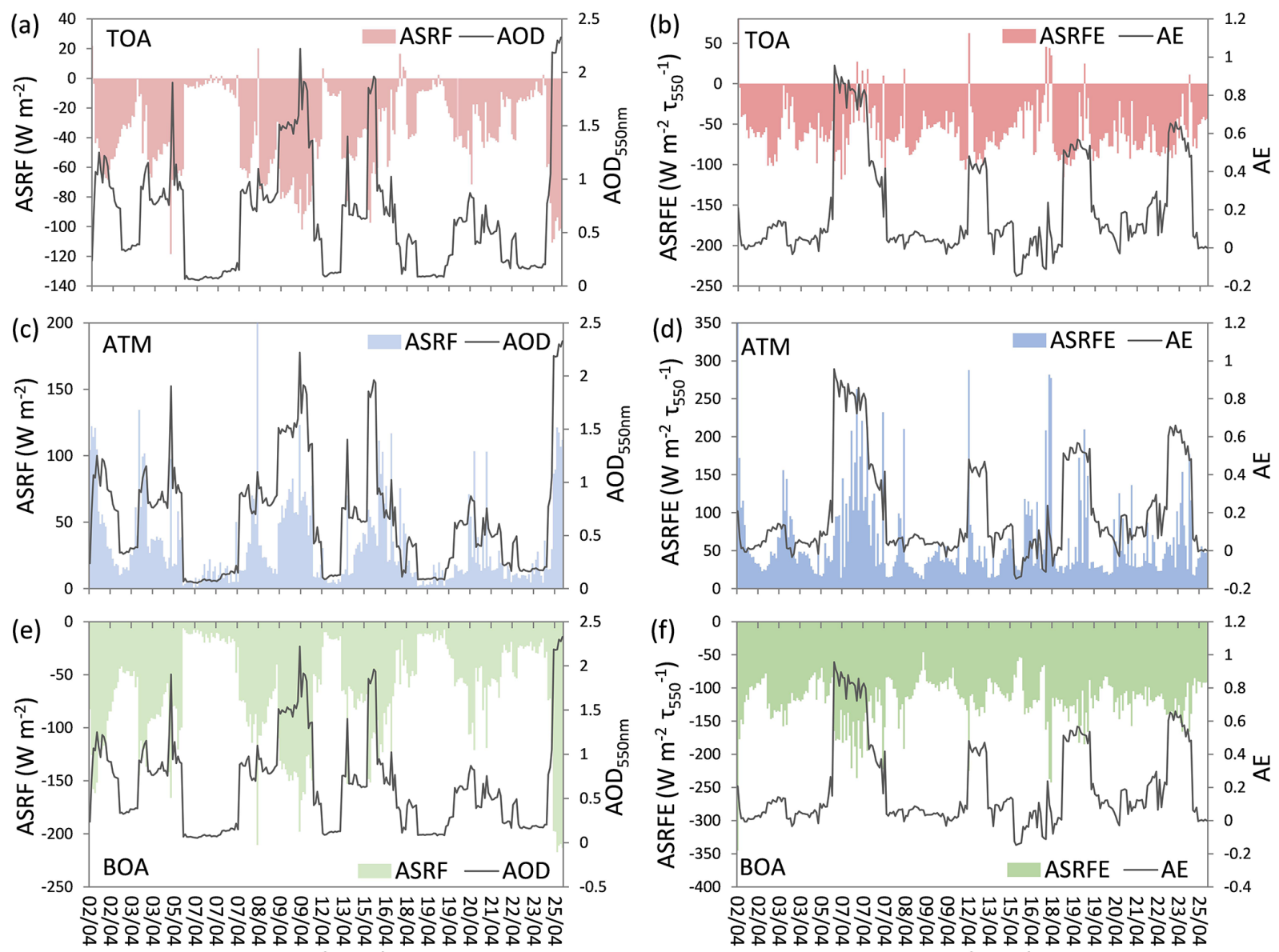

Date (2019)

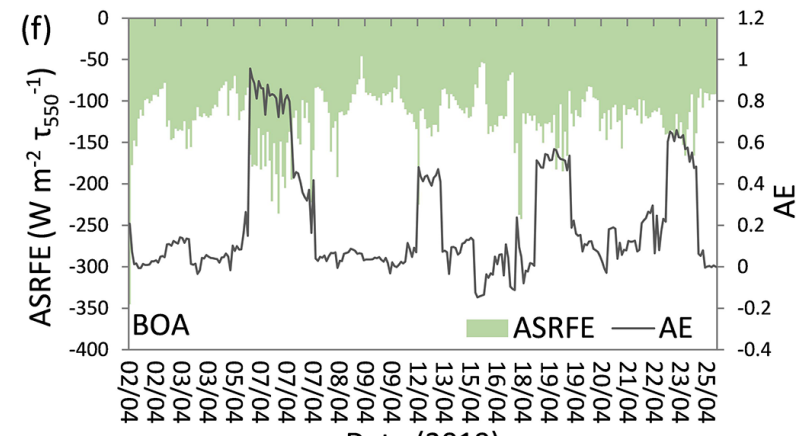

Figure 5. Instantaneous aerosol solar radiative forcing (a, c, e) and efficiencies $(\mathbf{b}, \mathbf{d}, \mathbf{f})$ at the Kashi site during the DAO-K campaign $(\mathbf{a}, \mathbf{b}$ : TOA; c, d: ATM; e, f: BOA).

free and low aerosol loading day at Kashi with AOD at $550 \mathrm{~nm}$ less than 0.22 for the whole day. As discussed above, the highest $\mathrm{AE}$ is observed on this day during the 1-month campaign (see Fig. 4). Both cooling and warming effects of aerosols can be found at the top of atmosphere. The cooling effects of ASRF are up to $-19 \mathrm{~W} \mathrm{~m}^{-2}$ at the TOA and $-48 \mathrm{~W} \mathrm{~m}^{-2}$ at the BOA, and the warming effect of ASRF is up to $50 \mathrm{~W} \mathrm{~m}^{-2}$ in the atmosphere. The corresponding extreme ASRFE values are $-126,-236$, and $263 \mathrm{~W} \mathrm{~m}^{-2} \tau_{550}^{-1}$, respectively. It is apparent that the changes of ASRFE are more intense than the corresponding ASRF for the clear case.

\subsubsection{Heavy dust case}

Figure 7 describes ASRF and ASRFE for a heavy dust storm episode on 25 April 2019 at Kashi. Only few observations from 03:33 to 04:11 UTC were suitable for retrieval in this day. Aerosol optical depth at $550 \mathrm{~nm}$ was up to 2.3 during this observation period. In comparison to the clear case, dust particles have stronger cooling effects at the TOA and BOA (ASRFs up to -111 and $-217 \mathrm{~W} \mathrm{~m}^{-2}$, respectively), and stronger warming effect in ATM (ASRF up to $121 \mathrm{~W} \mathrm{~m}^{-2}$ ). However, we observe the extreme ASRFE values of -51 , -99 , and $55 \mathrm{~W} \mathrm{~m}^{-2} \tau_{550}^{-1}$ at the TOA, BOA, and in ATM, respectively, indicating that the radiative forcing of dust is less efficient than that of the clear case. Moreover, the variations of ASRFE in the dust case are more moderate than those of ASRF. These are striking differences from the clear-sky case.

\subsubsection{Two-layer dust case}

On 9 April 2019, one extra layer suspending above the planetary boundary layer (PBL) was observed. Figure 8 illustrates the observations of LILAS on 8 April. Lidar observations on 9 April 2019 are not shown because the lidar stopped working due to technical problems on the night of 8 April 2019. According to the backscattering coefficient profiles at $355 \mathrm{~nm}$, the lower layer and upper layer can be clearly identified. Lidar measurements indicate that aerosols in the layer above the PBL are probably dust particles because the derived high depolarization ratios agree with the values for dust. However, we cannot draw unambiguous con- 

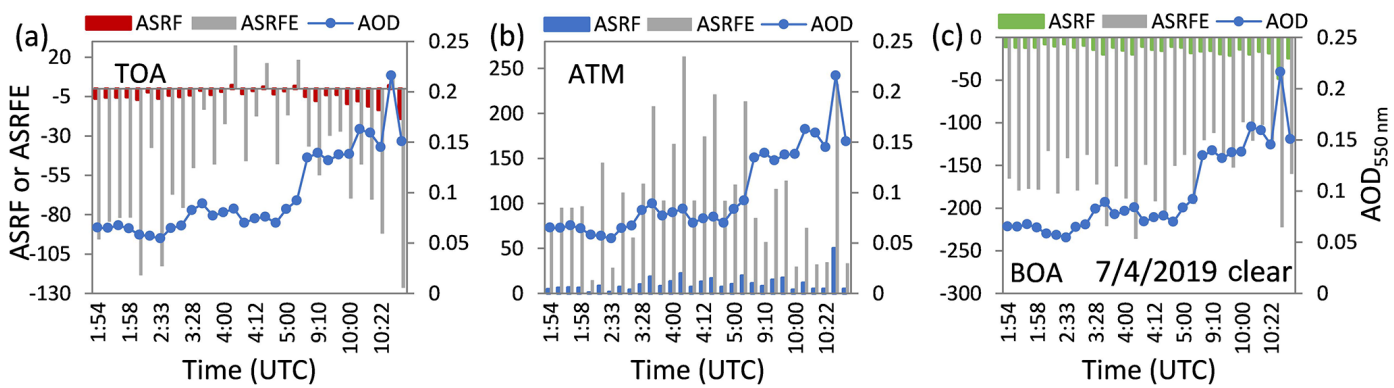

Figure 6. Instantaneous aerosol solar radiative forcing and efficiencies of the clear-sky case on 7 April 2019 at the Kashi site: (a) TOA, (b) ATM, and (c) BOA.
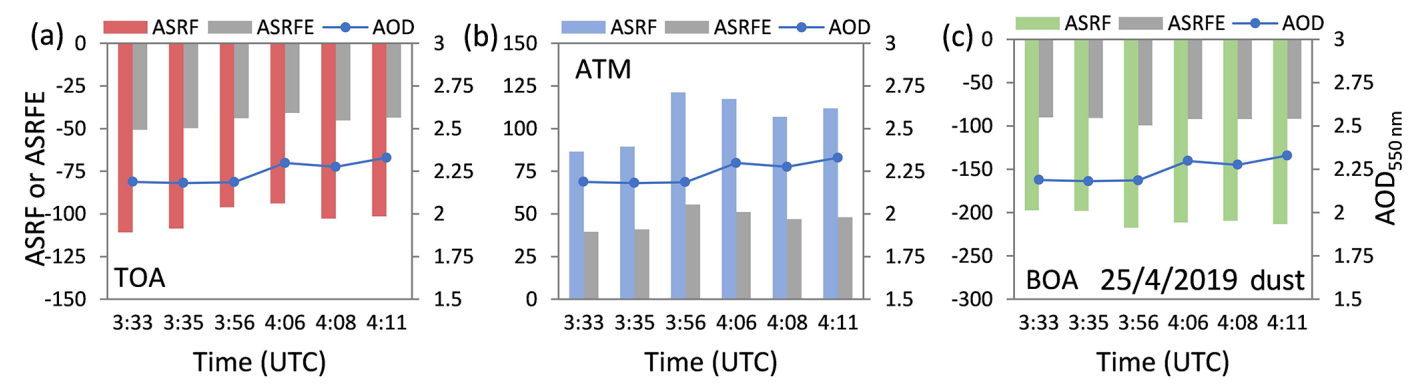

Figure 7. As Fig. 6 but for the heavy dust case on 25 April 2019.

clusions from lidar measurements about the aerosol type in the PBL, because the incomplete overlap range of the lidar system is up to $800-1000 \mathrm{~m}$. From Fig. 4, high AOD corresponding to low $\mathrm{AE}$ in the whole atmosphere and high $\mathrm{PM}_{2.5}$ and $\mathrm{PM}_{10}$ concentrations in the surface layer are exhibited from 8 to 9 April. It also suggests the complex pollution by two-layer dust particles during this pollution process. AOD at $550 \mathrm{~nm}$ on 9 April changes from 1.4 to 2.2 (Fig. 9). Consistent with the above heavy dust case, only cooling effects can be observed at the TOA and BOA, and only warming effect can be found in ATM for this case. The two layers of dust particles result in a TOA cooling effect up to $-102 \mathrm{~W} \mathrm{~m}^{-2}$, BOA cooling effect of up to $-198 \mathrm{~W} \mathrm{~m}^{-2}$, and atmosphere warming effect of up to $123 \mathrm{~W} \mathrm{~m}^{-2}$. The absolute values of ASRF at the TOA and BOA in this case are all less than those in the heavy dust case, suggesting the aerosols in the heavy dust case have more powerful cooling effects. Nevertheless, the extreme values of ASRFE are -62, -105 , and $58 \mathrm{~W} \mathrm{~m}^{-2} \tau_{550}^{-1}$ at the TOA, BOA, and in ATM, respectively, indicating that dust particles in the two-layer case have stronger radiative forcing efficiencies than those in the heavy dust cases.

\subsection{Influence of the atmosphere and surface conditions}

Figure 10 describes the influence of atmospheric profile and land surface albedo on the simulations of total irradiances and ASRF. The differences in the results of total downward irradiance (TDI), total upward irradiance (TUI), and ASRF

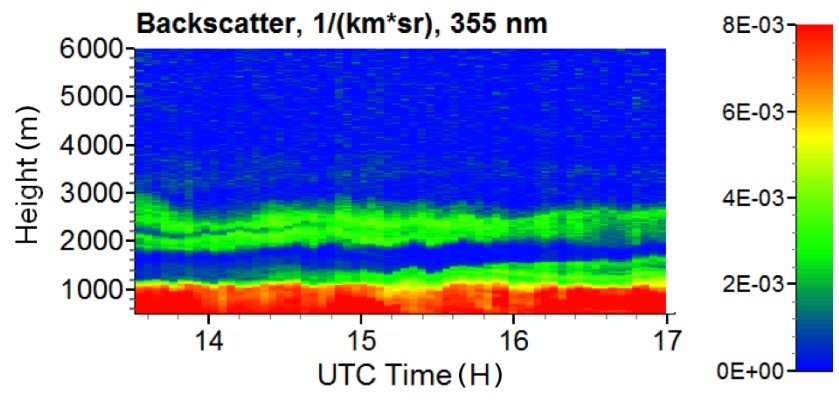

Figure 8. The backscattering coefficient profiles at $355 \mathrm{~nm}$ for the two-layer dust case on the night of 8 April 2019.

at the TOA and BOA simulated with the pre-defined midlatitude winter profile and user-specified profiles, and simulated with local noon surface albedo and instantaneous surface albedo are given, respectively. According to Fig. 10a, different settings of profiles have no influence on the TDI at the TOA. For the TUI, the absolute differences are less than $9 \mathrm{~W} \mathrm{~m}^{-2}$. However, the atmospheric profile has significant impacts on both the TDI and TUI at the surface. The influence on TDI is generally stronger than which on TUI. The maximum absolute difference is up to $138 \mathrm{~W} \mathrm{~m}^{-2}$ (Fig. 10c). For ASRF at the TOA, the effects of atmospheric profiles are less than $5 \mathrm{~W} \mathrm{~m}^{-2}$. However, the serious influence of atmospheric profiles on ASRF can be up to $103 \mathrm{~W} \mathrm{~m}^{-2}$ at the BOA (Fig. 10e). The average effect of different profiles on ASRF is $0.8 \mathrm{~W} \mathrm{~m}^{-2}$ at the TOA, which is quite small in com- 

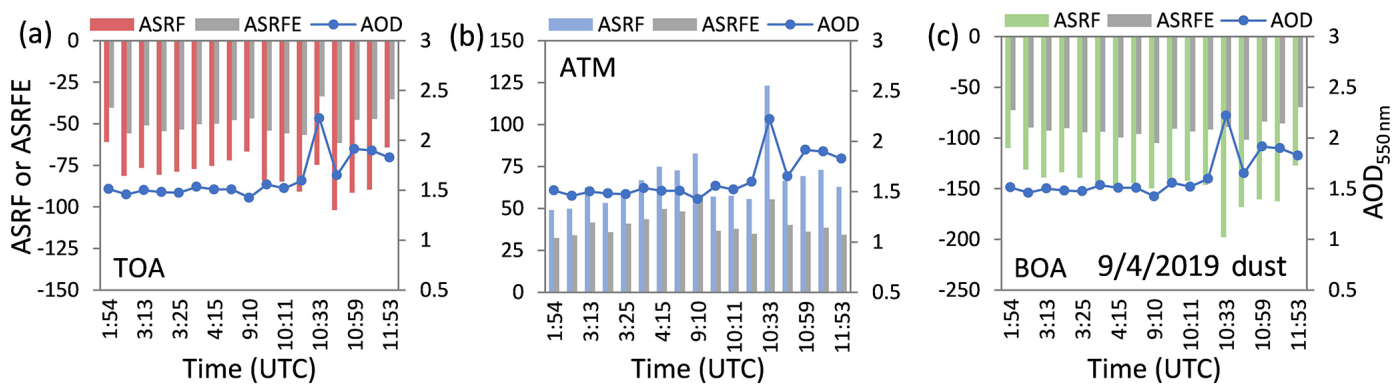

Figure 9. As Fig. 6 but for the two-layer dust case on 9 April 2019.

parison with the average values of daily $\operatorname{ASRF}\left(-19 \mathrm{~W} \mathrm{~m}^{-2}\right)$. However, the average difference of $13 \mathrm{~W} \mathrm{~m}^{-2}$ for ASRF affected by atmospheric profiles cannot be ignored relative to the average ASRF $\left(-36 \mathrm{~W} \mathrm{~m}^{-2}\right)$ at the BOA. As a result, the cooling effects of aerosol radiative forcing will be significantly underestimated at the BOA simulated with the pre-defined midlatitude winter profile instead of the userspecified Kashi atmospheric profiles.

Like atmospheric profile, different settings of LSA have also no influence on TDI at the TOA (Fig. 10b). They have small effects on TDI at the BOA (absolute difference less than $3 \mathrm{~W} \mathrm{~m}^{-2}$ ) but obvious impacts on TUI at the TOA and BOA (absolute difference up to $22 \mathrm{~W} \mathrm{~m}^{-2}$ ) (Fig. 10b, d). From Fig. 3, the local noon albedo is often less than the daily mean albedo. Especially for a clear day, the minimum of LSA occurs around the local noon. Then, the TUI at the TOA and BOA will generally be underestimated by using the local noon albedo instead of instantaneous surface albedo in the simulations. But for ASRF (Fig. 10f), two LSA settings lead to moderate impacts at the TOA and BOA with average absolute differences of 1.8 and $1.7 \mathrm{~W} \mathrm{~m}^{-2}$, respectively. Therefore, simulations using the local noon albedo tend to overestimate the cooling effects of the aerosol radiative forcing both at the TOA and BOA.

\subsection{Difference from AERONET products}

Aerosol radiative forcing at the TOA and BOA involves operational products provided routinely by AERONET. Measurements of CE318 no. 1141 during the DAO-K campaign have been processed by AERONET. Therefore, we can compare the ASRF product from AERONET with our simulations. For AERONET, broadband upward and downward irradiances in the SW range from 0.2 to $4.0 \mu \mathrm{m}$ were calculated by radiative transfer model with retrieved aerosol properties as model inputs (http://aeronet.gsfc.nasa.gov, last access: July 2019). However, AERONET adopts a different definition of ASRF, only taking the downward irradiance at the BOA and the upward irradiance at the TOA into consideration (García et al., 2012). The upward irradiances with and without aerosols in Eq. (2), along with the downward irradiances with and without aerosols in Eq. (1), are not taken into account. Omitting the downward irradiances will not make much difference in ASRF at the TOA. But for ASRF at the $\mathrm{BOA}$, it is predictable that neglecting the upward irradiance will lead to an obvious difference. Some existing studies have executed this kind of comparison (García et al., 2008, 2012; Bi et al., 2014) and reported that AERONET tends to overestimate aerosol ASRF at the BOA (García et al., 2012).

Figure 11 presents the correlations of instantaneous aerosol ASRF between the RT model simulations and the AERONET products. It is obvious that there are linear relationships between our RT simulations and the AERONET results with $R^{2}$ up to 0.98 and 0.99 at the TOA and BOA, respectively. Two ASRF results at the TOA show good consistency with a slope of 1.01 , even though the calculated SW ranges are not an exact match (i.e., $0.28-3.0 \mu \mathrm{m}$ for this study and $0.2-4.0 \mu \mathrm{m}$ for AERONET). But, for BOA, the AERONET products are obviously stronger than the corresponding RT model simulations (with a slope of 1.24), which agrees with the conclusion of the previous study (García et al., 2012).

\section{Comparison with WRF-Chem simulations}

\subsection{Comparison between radiative transfer and WRF-Chem simulations}

Figure 12 compares the assimilated aerosols to the observations. Evidently, the assimilation greatly improves the particulate matter concentrations and show reasonable variations in accordance with the dust episodes. However, two disadvantages are noticeable. One is that the assimilation fails to reproduce the extremely high $\mathrm{PM}_{2.5}$ and $\mathrm{PM}_{10}$ on 24 25 April 2019, because the background error covariance is not specific for the model error in the strong dust storm. A better model result for the specific dust storm requires improving the model capability of simulating dust emission and the transport of dust particulates besides data assimilation. Another is the assimilated AOD indeed increases but not well approaches the observations. The reason is that we only assimilated AOD by assuming the invariable extinction coefficients. Hence, this low bias in AOD cannot be eliminated by 

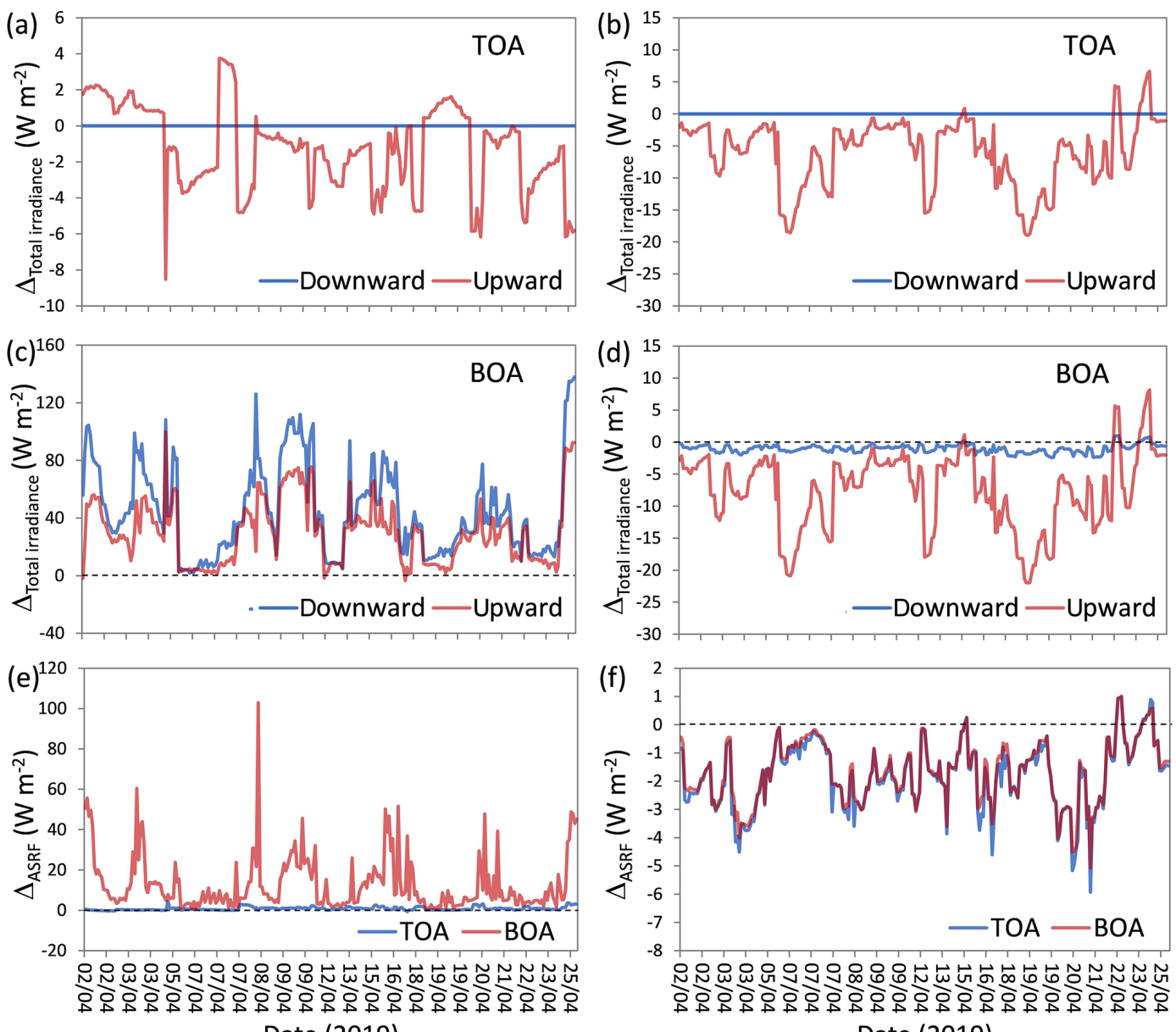

Date (2019)

Date (2019)

Figure 10. Influence of atmospheric profile (a, c, e) and land surface albedo (b, d, f) on total irradiances and ASRF. (a) Differences of total downward and upward irradiances (TDI and TUI) at the TOA between simulations with the pre-defined midlatitude winter profile and userspecified profiles; (b) differences of TDI and TUI at the TOA between simulations with local noon surface albedo and instantaneous surface albedo; panel (c) is the same as (a) but for BOA; panel (d) is the same as (b) but for BOA; (e) differences of ASRF between simulations with the pre-defined midlatitude winter profile and user-specified profiles at the TOA and BOA; (f) differences of ASRF between simulations with local noon surface albedo and instantaneous surface albedo at the TOA and BOA.
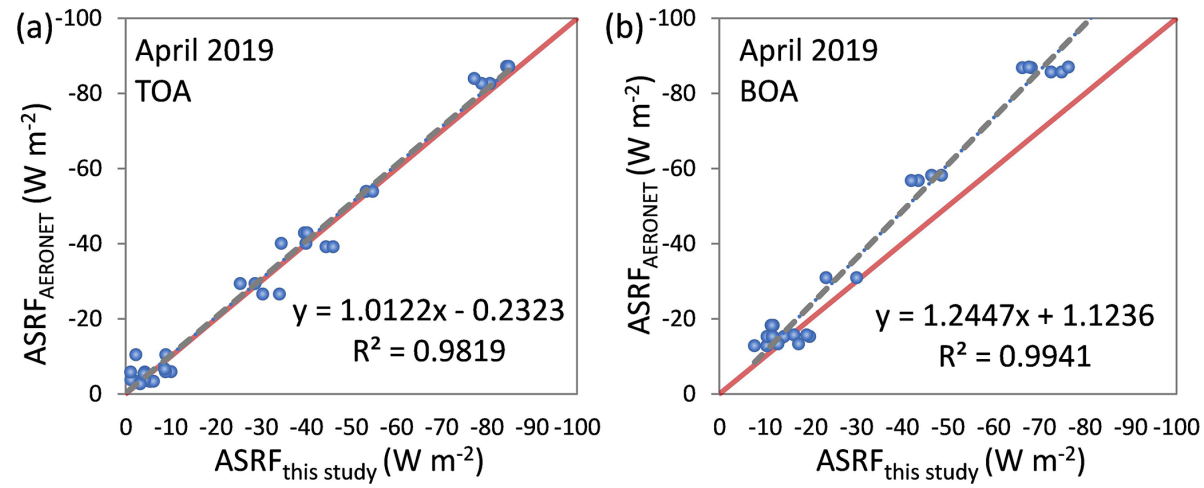

Figure 11. Correlations of instantaneous ASRF between radiative transfer (RT) model simulations in this study and the AERONET products during the DAO-K campaign: (a) TOA and (b) BOA. 

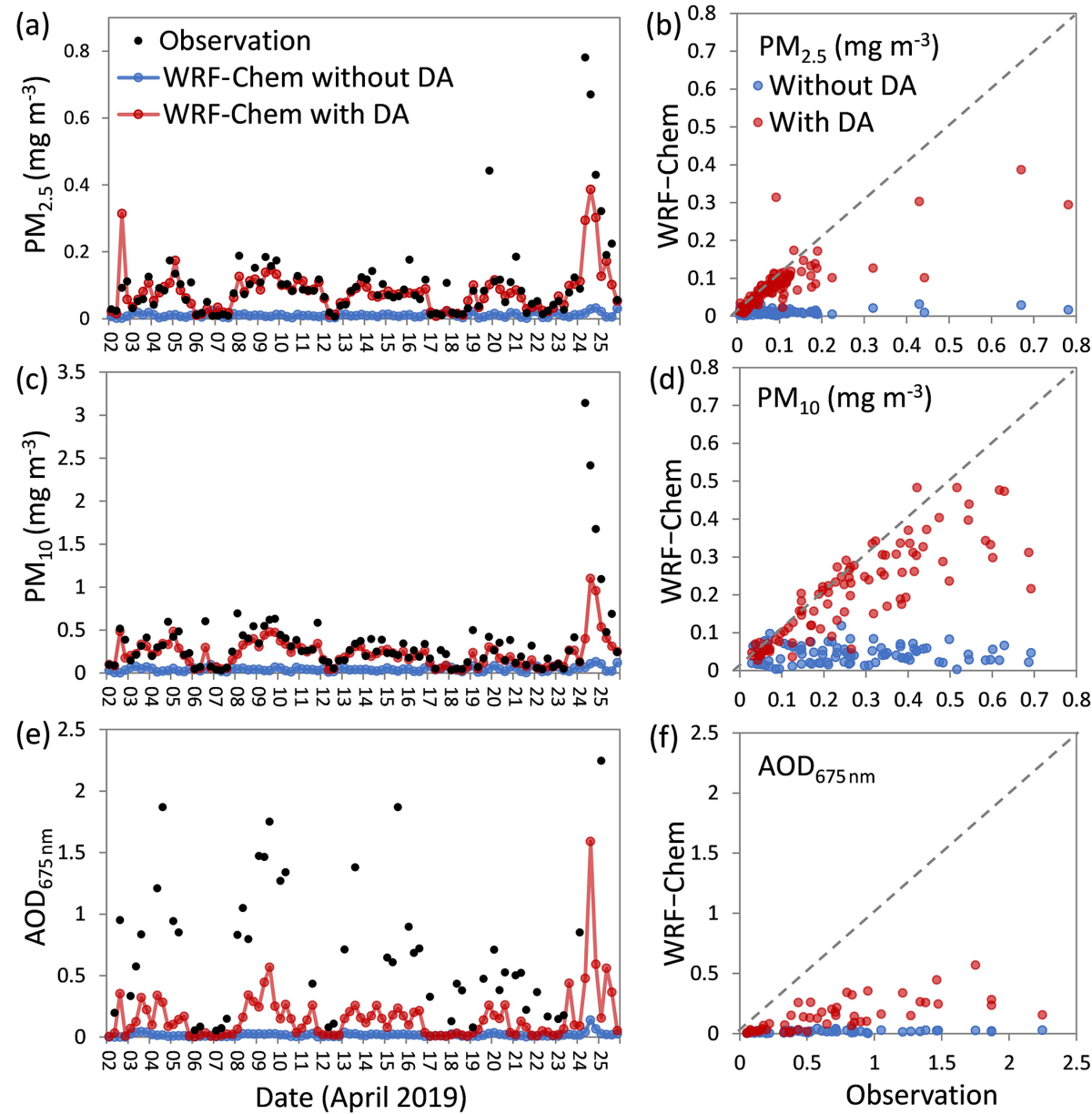

Figure 12. Comparisons of the surface-layer $\mathrm{PM}_{2.5}(\mathbf{a}, \mathbf{b})$ and $\mathrm{PM}_{10}(\mathbf{c}, \mathbf{d})$ concentrations and AOD at 675 nm $(\mathbf{e}, \mathbf{f})$ among the observations, the WRF-Chem simulations with and without data assimilation (DA) in April 2019. The observations have been interpolated to 00:00, 06:00, 12:00, and 18:00 UTC of each day.

choosing a scaling factor smaller than $50 \%$ in the observation error for that it will damage the surface-layer particulate results.

Figure 13 illustrates the results of daily mean ASRFs during DAO-K campaign simulated by the SBDART and WRFChem models. The two results show similar variation patterns. However, there are obvious differences between the WRF-Chem results and the RT simulations in some dustpolluted cases (e.g., 9, 24, and 25 April 2019). According to the RT simulations, the strongest radiative forcing occurred on 25 April 2019. However, the most significant ASRF of WRF-Chem simulation is found on 24 April 2019, followed by 25 April 2019. As mentioned above, heavy dust storms broke out on these $2 \mathrm{~d}$ during the DAO-K campaign. The percent differences are sometimes greater than $50 \%$ between the RT and WRF-Chem simulations. The significant differences between the two kinds of simulated results should be further evaluated.

\subsection{Validation by ground-based irradiance measurements}

Figure 14 directly compares the RT and WRF-Chem simulated downward irradiances at surface with the ground-based measurements under three different sky conditions (i.e., clear case, heavy dust case, and two-layer dust case). The RT simulations of total, direct, and diffuse downward irradiances in the three situations agree well with high-precision measurements of pyrheliometer and pyranometers. The percent differences of RT-simulated total irradiance with respect to the measurements are only $0.03 \%$ for the clear case, $-2.67 \%$ for the heavy dust case, and $-0.43 \%$ for the two-layer dust case. Except for the heavy dust case, they are within the pyranometer measurement uncertainties $(0.66 \%)$. As for the WRF-Chem simulations, the total irradiances in the clearsky case are consistent with RT simulations and measurements (Fig. 14a). But for the direct irradiances, there are obvious differences between the WRF-Chem simulations and the corresponding measurements (Fig. 14b). Moreover, the 


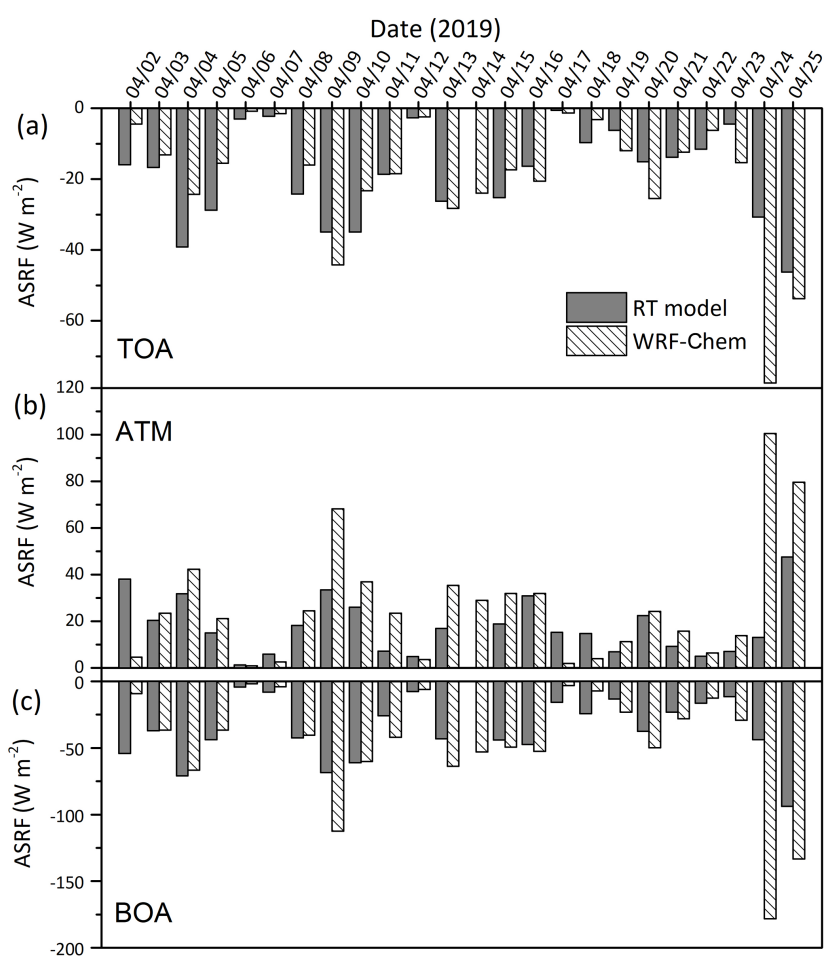

Figure 13. Comparisons of daily mean ASRF between the RT model calculations and the WRF-Chem simulations during the DAO-K campaign: (a) TOA, (b) ATM, and (c) BOA.

WRF-Chem simulated diffuse irradiances in the clear case (Fig. 14c), the total, direct, and diffuse irradiances in the heavy dust and two-layer dust cases (Fig. 14d-i) are significantly distinct from the measurements and RT simulations.

One of the most noticeable features in the curves of WRFChem results is the sudden jump around 06:00 UTC, which can be attributed to data assimilation restarting at 06:00 UTC and running to the next analysis time (12:00 UTC). The WRF-Chem results are greatly improved after 06:00 UTC in the dust-polluted cases. It is evident that data assimilation can ameliorate the WRF-Chem simulations in dust cases, but the correction effects are still limited. So, the problems of the WRF-Chem simulation have not yet been fully resolved by the assimilation of aerosol optical depth and particulate matter concentrations. This conclusion is in accordance with Figs. 12 and 13. Our measurements have proved that the simulations of RT model are reliable in both of clear and high aerosol loading situations. The WRF-Chem model performs better in clear-sky than in the dust-polluted conditions. There is still room for improving the WRF-Chem simulation of dust aerosol radiative forcing.

\section{Summary and conclusions}

Dust aerosol particles play an important role in local and global climate changes by influencing the solar radiation budget through scattering and absorbing processes, especially for the regions close to dust sources such as deserts. The complicated scattering and absorption characteristics of dust particles make it challenging to estimate their direct radiative forcing. To overcome some of the issues with the quantification of the dust radiative effects, the Dust Aerosol Observation-Kashi (DAO-K) campaign was designed and performed near the Taklimakan Desert, which represents a substantial and stable source of Asian dust aerosol particles. For almost 1 month, comprehensive observations of aerosol properties (i.e., aerosol optical depth, Ångström exponent, single scattering albedo, and asymmetry factor), atmospheric profiles (including ozone measurements), and land surface properties were obtained by a variety of stateof-the-art ground-based and satellite instruments in the dust season, and were applied to estimate the aerosol solar radiative forcing using the SBDART radiative transfer model. In addition to high-quality datasets of volumetric aerosol properties, satisfying the AERONET and SONET level-1.5 data criteria, the daily specified atmospheric profiles and diurnal variations of surface albedo were also considered in the calculations. The results simulated with the SBDART model show that the average values of daily mean ASRF at Kashi are $-19 \mathrm{~W} \mathrm{~m}^{-2}$ at the TOA and $-36 \mathrm{~W} \mathrm{~m}^{-2}$ at the BOA during the DAO-K campaign. The dust-dominant aerosol particles have stronger cooling effects at both the TOA and BOA, and more significant warming effects in the atmosphere than other low aerosol loading situations. Nevertheless, the radiative forcing efficiencies in dust-polluted cases are lower than those in clear-sky conditions. The average influence of different profiles on ASRF is small at the TOA $\left(0.8 \mathrm{~W} \mathrm{~m}^{-2}\right)$ but remarkable at the BOA $\left(13 \mathrm{~W} \mathrm{~m}^{-2}\right)$. The cooling effects of aerosol radiative forcing at the BOA are significantly underestimated by simulations with the pre-defined midlatitude winter profile instead of the user-specified profiles measured at Kashi during the DAO-K campaign. Simulations using the local noon albedo tend to overestimate the cooling effects of the aerosol radiative forcing both at the TOA and BOA. Different land surface albedo settings (i.e., local noon albedo or instantaneous albedo) lead to moderate impacts on ASRF with average effects of $1.8 \mathrm{~W} \mathrm{~m}^{-2}$ at the TOA and $1.7 \mathrm{~W} \mathrm{~m}^{-2}$ at the BOA.

By assimilating the multi-wavelength columnar AOD and the surface-based measurements of $\mathrm{PM}_{2.5}$ and $\mathrm{PM}_{10}$ mass concentrations, the aerosol solar radiative forcing was also simulated for the time period of the DAO-K field campaign using the WRF-Chem model. The downward solar irradiance measurements at the surface were used as a reference in evaluating the RT and WRF-Chem simulations. The direct, diffuse (and the sum of both) downward irradiances simulated by the SBDART model in the clear-sky, heavy dust, and two-layer dust conditions are all in sufficient agreement with ground-based measurements. As for the WRF-Chem simulations, the total irradiances in the clear-sky case are consistent with RT calculations and measurements. But the di- 

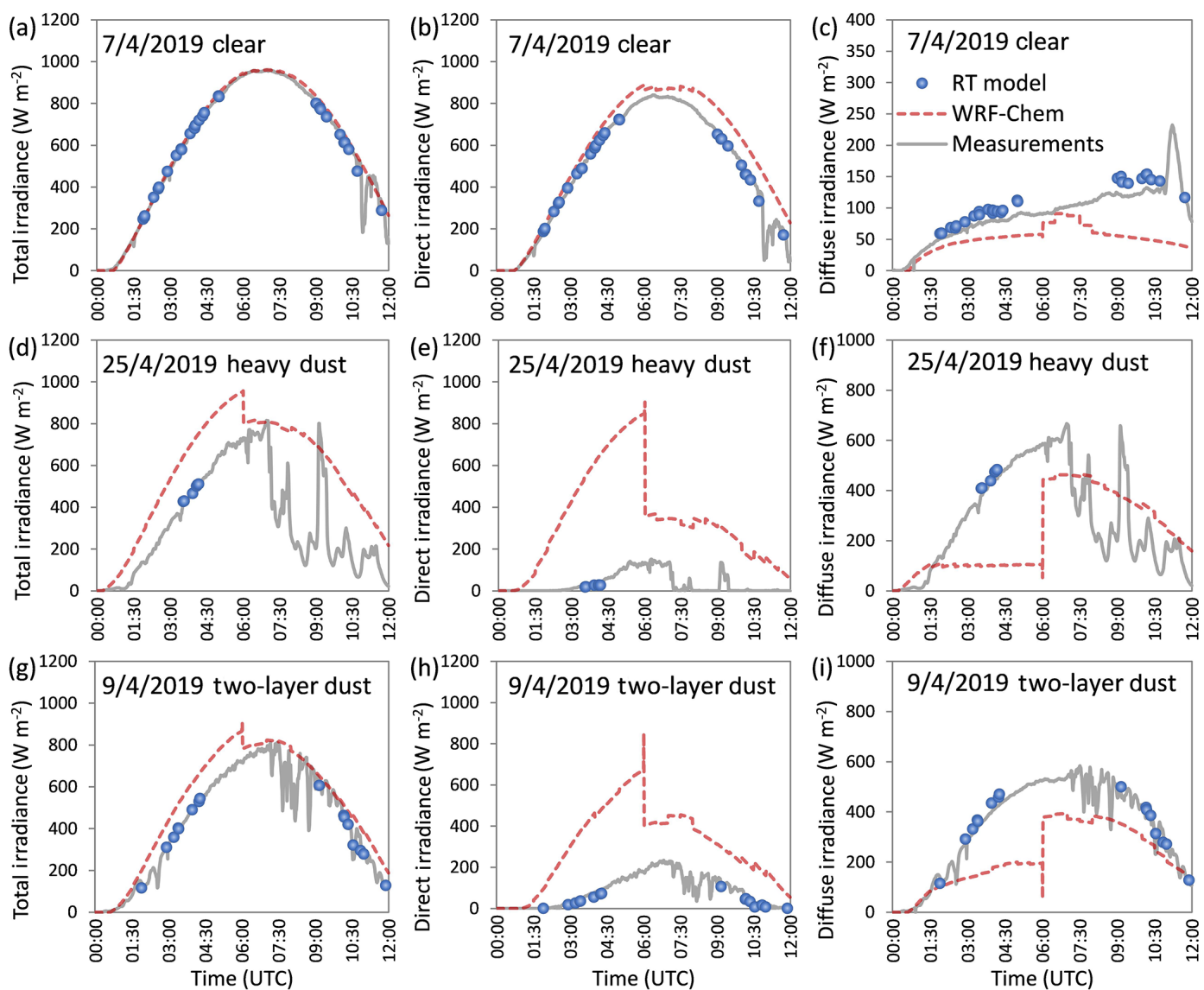

Figure 14. Comparisons of total, direct, and diffuse downward irradiances at the bottom of atmosphere for the clear-sky case (a-c), the heavy dust case (d-f), and the two-layer dust case (g-i) at the Kashi site (blue points: simulated by the RT model; dashed red lines: simulated by the WRF-Chem model with data assimilation at 00:00 and 06:00 UTC; solid gray lines: measured by pyrheliometer and pyranometers).

rect, diffuse, and total irradiances simulated by WRF-Chem significantly deviate from measurements in the dust-polluted situations. Based on these findings, it is concluded that the SBDART model provides credible estimates of dust particle solar radiative forcing if supplied with appropriate model input data. Data assimilation can obviously improve the WRFChem simulations in dust cases, but the correction effects are still limited. Consideration of the actual measured atmospheric profiles and diurnal cycles of land surface albedo has some potential to improve the RT simulations. Optimizations of dust emission scheme, background error setting of dust assimilation system, and dust parameterization including nonsphericity are proposed as promising approaches to improve the WRF-Chem simulations of dust radiative forcing. We would like to emphasize, however, that in this study the comparisons are conducted at one site and in a limited time period. Future research on this topic should include a systematic evaluation of RT and WRF-Chem simulations on extended space scales and timescales.
Data availability. The MODIS, OMI, and AERONET products can be accessed at https://ladsweb.modaps.eosdis.nasa.gov/ search/ (last access: July 2019), https://disc.gsfc.nasa.gov/ (last access: July 2019), and https://aeronet.gsfc.nasa.gov/ (last access: July 2019), respectively.

Author contributions. ZL, PG, LL, KL, and JW designed the Dust Aerosol Observation-Kashi (DAO-K) campaign. YO and CL conducted the measurements of the solar radiation monitoring station and the all-sky view camera. YO collected and processed the data of atmospheric profiles. $\mathrm{QH}$ performed the lidar observations. The retrievals of aerosol properties were processed and provided by KL. The WRF-Chem simulations and analysis were provided by WC. LL improved the SBDART simulations and conducted data analysis and comparisons. LL and MW prepared the paper with contributions from all authors.

Competing interests. The authors declare that they have no conflict of interest. 
Special issue statement. This article is part of the special issue "Satellite and ground-based remote sensing of aerosol optical, physical, and chemical properties over China". It is not associated with a conference.

Acknowledgements. The authors acknowledge the MODIS, OMI, and AERONET groups for making the surface albedo, ozone profile, and radiative forcing products available, respectively. We also thank the Kashi regional meteorological bureau and the China National Environmental Monitoring Center for providing the data of atmospheric sounding and $\mathrm{PM}_{10}$ concentrations of Kashi, respectively. The Anhui Yunnengtian Intelligent Technology Co., Ltd., China, is acknowledged for providing the all-sky view camera and technical support. The first author also wishes to thank Haofei Wang, Thierry Podvin, Igor Veselovskiy, Jie Chen, and Ying Zhang for participating in the measurements. We are grateful to the anonymous reviewers whose valuable comments and suggestions have helped us to improve the paper.

Financial support. This research has been supported by the National Natural Science Foundation of China (grant no. 41871271) and the National Key R\&D Program of China (grant no. 2016YFE0201400).

Review statement. This paper was edited by Jianping Huang and reviewed by two anonymous referees.

\section{References}

Adesina, A. J., Kumar, K. R., Sivakumar, V., and Griffith, D.: Direct radiative forcing of urban aerosols over Pretoria $\left(25.75^{\circ} \mathrm{S}\right.$, $28.28^{\circ} \mathrm{E}$ ) using AERONET Sunphotometer data: first scientific results and environmental impact, J. Environ. Sci., 26, 24592474, https://doi.org/10.1016/j.jes.2014.04.006, 2014.

Ansmann, A., Petzold, A., Kandler, K., Tegen, I., Wendisch, M., Müller, D., Weinzierl, B., Müller, T., and Heintzenberg, J.: Saharan Mineral Dust Experiments SAMUM-1 and SAMUM-2: What have we learned? Tellus B, 63, 403-429, https://doi.org/10.1111/j.1600-0889.2011.00555.x, 2011.

Babu, S. S., Satheesh, S. K., and Moorthy, K. K.: Aerosol radiative forcing due to enhanced black carbon at an urban site in India, Geophys. Res. Lett., 29, 27-21, https://doi.org/10.1029/2002GL015826, 2002.

Bhartia, P. K., Mcpeters, R. D., Mateer, C. L., Flynn, L. E., and Wellemeyer, C. G.: Algorithm for the estimation of vertical ozone profiles from the backscattered ultraviolet technique, J. Geophys. Res., 101, 18793-18806, https://doi.org/10.1029/96JD01165, 1996.

Bi, J., Huang, J., Hu, Z., Holben, B. N., and Guo, Z.: Investigating the aerosol optical and radiative characteristics of heavy haze episodes in Beijing during January of 2013, J. Geophys. Res.-Atmos., 119, 9884-9900, https://doi.org/10.1002/2014JD021757, 2014.

Bi, L., Yang, P., Kattawar, G. W., and Kahn, R.: Modeling optical properties of mineral aerosol particles by us- ing nonsymmetric hexahedra, Appl. Optics, 49, 334-342, https://doi.org/10.1364/AO.49.000334, 2010.

Bierwirth, E., Wendisch, M., Ehrlich, A., Heese, B., Tesche, M., Althausen, D., Schladitz, A., Müller, D., Otto, S., Trautmann, T., Dinter, T., von Hoyningen-Huene, W., and Kahn, R.: Spectral surface albedo over Morocco and its impact on radiative forcing of Saharan dust, Tellus B, 61, 252-269, https://doi.org/10.1111/j.1600-0889.2008.00395.x, 2009.

Bory, A. J., Biscaye, P. E., and Grousset, F. E.: Two distinct seasonal Asian source regions for mineral dust deposited in Greenland (NorthGRIP), Geophys. Res. Lett., 30, 1167, https://doi.org/10.1029/2002GL016446, 2003.

Chen, F., and Dudhia, J.: Coupling an advanced land surfacehydrology model with the Penn State-NCAR MM5 modeling system. Part I: Model implementation and sensitivity, Mon. Wea. Rev., 129, 569-585, https://doi.org/10.1175/15200493(2001)129,0569: CAALSH.2.0.CO;2, 2001.

Chen, S., Huang, J., Zhao, C., Qian, Y., Leung, L. R., and Yang, B.: Modeling the transport and radiative forcing of Taklimakan dust over the Tibetan Plateau: A case study in the summer of 2006, J. Geophys. Res.-Atmos., 118, 797-812, https://doi.org/10.1002/jgrd.50122, 2013.

Chen, S., Zhao, C., Qian, Y., Leung, L. R., Huang, J., Huang, Z., Bi, J., Zhang, Y., Shi, J., Yang, L., Li, D., and Li, J.: Regional modeling of dust mass balance and radiative forcing over East Asia using WRF-Chem, Aeolian Research, 15, 15-30, https://doi.org/10.1016/j.aeolia.2014.02.001, 2014.

Chen, S., Huang, J., Li, J., Jia, R., Jiang, N., Kang, L., Ma, X., and Xie, T.: Comparison of dust emissions, transport, and deposition between the Taklimakan Desert and Gobi Desert from 2007 to 2011, Science China Earth Sciences, 60, 1338-1355, https://doi.org/10.1007/s11430-016-9051-0, 2017.

Chen, S., Yuan, T., Zhang, X., Zhang, G., Feng, T., Zhao, D., Zang, Z., Liao, S., Ma, X., Jiang, N., Zhang, J., Yang, F., and Lu, H.: Dust modeling over East Asia during the summer of 2010 using the WRF-Chem model, J. Quant. Spectrosc. Ra., 213, 1-12, https://doi.org/10.1016/j.jqsrt.2018.04.013, 2018.

Chen, X., Guo, J., Yin, J., Zhang, Y., Miao, Y., Yun, Y., Liu, L., Li, J., Xu, H., Hu, K., and Zhai, P.: Tropopause trend across China from 1979 to 2016: A revisit with updated radiosonde measurements, Int. J. Climatol., 39, 1117-1127, https://doi.org/10.1002/joc.5866, 2019.

China Meteorological Administration: Operational specifications for conventional upper-air meteorological observations, China Meteorological Press, Beijing, China, 2010.

DeMott, P. J., Sassen, K., Poellot, M. R., Baumgardner, D., Rogers, D. C., Brooks, S. D., Prenni, A. J., and Kreidenweis, S. M.: African dust aerosols as atmospheric ice nuclei, Geophys. Res. Lett., 30, 1732, https://doi.org/10.1029/2003GL017410, 2003.

Dubovik, O., Sinyuk, A., Lapyonok, T., Holben, B. N., Mishchenko, M., Yang, P., Eck, T. F., Volten, H., Munõz, O., Veihelmann, B., van der Zande, W. J., Leon, J. F., Sorokin, M., and Slutsker, I.: Application of spheroid models to account for aerosol particle nonsphericity in remote sensing of desert dust, J. Geophys. Res., 111, D11208, https://doi.org/10.1029/2005JD006619, 2006.

Esteve, A. R., Estelles, V., Utrillas, M. P., and Martinezlozano, J. A.: Analysis of the aerosol radiative forcing over a Mediterranean urban coastal site, Atmos. Res., 137, 195-204, https://doi.org/10.1016/j.atmosres.2013.10.009, 2014. 
Fast, J. D., Gustafson Jr., W. I., Easter, R. C., Zaveri, R. A., Barnard, J. C., Chapman, E. G., Grell, G. A., and Peckham, S. E.: Evolution of ozone, particulates, and aerosol direct radiative forcing in the vicinity of Houston using a fully coupled meteorology-chemistry-aerosol model, J. Geophys. Res., 111, D21305, https://doi.org/10.1029/2005JD006721, 2006.

García, O. E., Díaz, A. M., Expósito, F. J., Díaz, J. P., Dubovik, O., Dubuisson, P., Roger, J. C., Eck, T. F., Sinyuk, A., Derimian, Y., Dutton, E. G., Schafer, J. S., Holben, B. N., and García, C. A.: Validation of AERONET estimates of atmospheric solar fluxes and aerosol radiative forcing by ground-based broadband measurements, J. Geophys. Res.-Atmos., 113, 6089-6098, https://doi.org/10.1029/2008JD010211, 2008.

García, O. E., Díaz, J. P., Expósito, F. J., Díaz, A. M., Dubovik, O., Derimian, Y., Dubuisson, P., and Roger, J.-C.: Shortwave radiative forcing and efficiency of key aerosol types using AERONET data, Atmos. Chem. Phys., 12, 5129-5145, https://doi.org/10.5194/acp-12-5129-2012, 2012.

Ginoux, P., Chin, M., Tegen, I., Prospero, J. M., Holben, B., Dubovik, O., and Lin, S. J.: Sources and distributions of dust aerosols simulated with the GOCART model, J. Geophys. Res., 106, 20255-20273, 2001.

Grell, G. A., Peckham, S. E., Schmitz, R., McKeen, S. A., Frost, G., Skamarock, W. C., and Eder, B.: Fully coupled "online" chemistry within the WRF model, Atmos. Environ., 39, 6957-6975, https://doi.org/10.1016/j.atmosenv.2005.04.027, 2005.

Guenther, A., Karl, T., Harley, P., Wiedinmyer, C., Palmer, P. I., and Geron, C.: Estimates of global terrestrial isoprene emissions using MEGAN (Model of Emissions of Gases and Aerosols from Nature), Atmos. Chem. Phys., 6, 3181-3210, https://doi.org/10.5194/acp-6-3181-2006, 2006.

Guo, J., Miao, Y., Zhang, Y., Liu, H., Li, Z., Zhang, W., He, J., Lou, M., Yan, Y., Bian, L., and Zhai, P.: The climatology of planetary boundary layer height in China derived from radiosonde and reanalysis data, Atmos. Chem. Phys., 16, 13309-13319, https://doi.org/10.5194/acp-16-13309-2016, 2016.

Guo, J., Li, Y., Cohen, J. B., Li, J., Chen, D., Xu, H., Liu, L., Yin, J., Hu, K., and Zhai, P.: Shift in the temporal trend of boundary layer height in china using long-term (19792016) radiosonde data, Geophys. Res. Lett., 46, 6080-6089, https://doi.org/10.1029/2019GL082666, 2019.

Holben, B. N., Eck, T. F., Slutsker, I., Tanré, D., Buis, J. P., Setzer, A., Vermote, E., Reagan, J. A., Kaufman, Y. J., Nakajima, T., Lavenu, F., Jankowiak, I., and Smirnov, A.: AERONET - A Federated Instrument Network and Data Archive for Aerosol Characterization, Remote Sens. Environ., 66, 1-16, 1998.

Hong, S. Y., Noh, Y., and Dudhia, J.: A new vertical diffusion package with an explicit treatment of entrainment processes, Mon. Weather Rev., 134, 2318-2341, https://doi.org/10.1175/MWR3199.1, 2006.

Hu, Q., Goloub, P., Veselovskii, I., Bravo-Aranda, J.-A., Popovici, I. E., Podvin, T., Haeffelin, M., Lopatin, A., Dubovik, O., Pietras, C., Huang, X., Torres, B., and Chen, C.: Long-rangetransported Canadian smoke plumes in the lower stratosphere over northern France, Atmos. Chem. Phys., 19, 1173-1193, https://doi.org/10.5194/acp-19-1173-2019, 2019.

Huang, J., Fu, Q., Su, J., Tang, Q., Minnis, P., Hu, Y., Yi, Y., and Zhao, Q.: Taklimakan dust aerosol radiative heating derived from CALIPSO observations using the Fu-Liou radiation model with CERES constraints, Atmos. Chem. Phys., 9, 4011-4021, https://doi.org/10.5194/acp-9-4011-2009, 2009.

Huang, J., Wang, T., Wang, W., Li, Z., and Yan, H.: Climate effects of dust aerosols over East Asian arid and semiarid regions, J. Geophys. Res.-Atmos., 119, 11398-11416, https://doi.org/10.1002/2014JD021796, 2014.

Iacono, M. J., Delamere, J. S., Mlawer, E. J., Shephard, M. W., Clough, S. A., and Collins, W. D.: Radiative forcing by long- lived greenhouse gases: Calculations with the AER radiative transfer models, J. Geophys. Res., 113, D13103, https://doi.org/10.1029/ 2008JD009944, 2008.

Intergovernmental Panel on Climate Change (IPCC): Climate change 2007: the physical science basis, Contribution of Working Group I to the Fourth Assessment Report of the Intergovernmental Panel on Climate Change, Cambridge University Press, Cambridge, UK, New York, USA, 2007.

Jäkel, E., Wendisch, M., and Mayer, B.: Influence of spatial heterogeneity of local surface albedo on the area-averaged surface albedo retrieved from airborne irradiance measurements, Atmos. Meas. Tech., 6, 527-537, https://doi.org/10.5194/amt-6527-2013, 2013.

Kaskaoutis, D. G., Kambezidis, H. D., Hatzianastassiou, N., Kosmopoulos, P. G., and Badarinath, K. V. S.: Aerosol climatology: dependence of the Angstrom exponent on wavelength over four AERONET sites, Atmos. Chem. Phys. Discuss., 7, 7347-7397, https://doi.org/10.5194/acpd-7-7347-2007, 2007.

Kleist, D. T., Parish, D. F., Derber, J. C., Treadon, R., Wu, W. S., and Lord, S.: Introduction of the GSI into the NCEP global data assimilation system, Weather Forecast., 24, 1691-1705, 2009.

Lenoble, J., Remer, L., and Tanré, D.: Aerosol Remote Sensing, Springer Berlin Heidelberg, https://doi.org/10.1007/978-3-64217725-5, 2013.

Lewis, P. and Barnsley, M. J.: Influence of the sky radiance distribution on various formulations of the earth surface albedo, Proc. Conf. Phys. Meas. Sign. Remote Sen. Val d'Isere, France, 707715, 1994.

Li, L., Li, Z., Dubovik, O., Zheng, X., Li, Z., Ma, J., and Wendisch, M.: Effects of the shape distribution of aerosol particles on their volumetric scattering properties and the radiative transfer through the atmosphere that includes polarization, Appl. Opt., 58, 1475-1484, https://doi.org/10.1364/AO.58.001475, 2019.

Li, R., Dong, X., Guo, J., Fu, Y., Zhao, C., Wang, Y., and Min, Q.: The implications of dust ice nuclei effect on cloud top temperature in a complex mesoscale convective system, Sci. Rep., 7, 13826, https://doi.org/10.1038/s41598-017-12681-0, 2017.

Li, Z., Blarel, L., Podvin, T., Goloub, P., Buis, J. P., and Morel, J. P.: Transferring the calibration of direct solar irradiance to diffuse-sky radiance measurements for CIMEL Sun-sky radiometers, Appl. Opt., 47, 1368-1377, https://doi.org/10.1364/AO.47.001368, 2008.

Li, Z. Q., Xu, H., Li, K. T., Li, D. H., Xie, Y. S., Li, L., Zhang, Y., Gu, X. F., Zhao, W., Tian, Q. J., Deng, R. R., Su, X. L., Huang, B., Qiao, Y. L., Cui, W. Y., Hu, Y., Gong, C. L., Wang, Y. Q., Wang, X. F., Wang, J. P., Du, W. B., Pan, Z. Q., Li, Z. Z., and Bu, D.: Comprehensive Study of Optical, Physical, Chemical, and Radiative Properties of Total Columnar Atmospheric Aerosols over China: An Overview of Sun-Sky Radiometer Observation Network (SONET) Measurements, B. Am. Meteorol. Soc., 99, 739-755, https://doi.org/10.1175/BAMS-D-17-0133.1, 2018. 
Liang, S.: Quantitative Remote Sensing of Land Surfaces, John Wiley, Hoboken, 2004.

Lin, Y. L., Farley, R. D., and Orville, H. D.: Bulk parameterization of the snow field in a cloud model, J. Climate Appl. Meteor., 22, 1065-1092, https://doi.org/10.1175/1520-0450(1983)022,1065: BPOTSF.2.0.CO;2, 1983.

Liu, L., Guo, J., Gong, H., Li, Z., Chen, W., Wu, R., Wang, L., Xu, H., Li, J., Chen, D., and Zhai, P.: Contrasting Influence of Gobi and Taklimakan Deserts on the Dust Aerosols in Western North America, Geophys. Res. Lett., 46, 9064-9071, https://doi.org/10.1029/2019GL083508, 2019.

Liu, J., Zheng, Y., Li, Z., Flynn, C., Welton, E. J., and Cribb, M.: Transport, vertical structure and radiative properties of dust events in southeast China determined from ground and space sensors, Atmos. Environ., 45, 6469-6480, https://doi.org/10.1016/j.atmosenv.2011.04.031, 2011a.

Liu, Z., Liu, D., Huang, J., Vaughan, M., Uno, I., Sugimoto, N., Kittaka, C., Trepte, C., Wang, Z., Hostetler, C., and Winker, D.: Airborne dust distributions over the Tibetan Plateau and surrounding areas derived from the first year of CALIPSO lidar observations, Atmos. Chem. Phys., 8, 5045-5060, https://doi.org/10.5194/acp8-5045-2008, 2008.

Liu, Z., Liu, Q., Lin, H. C., Schwartz, C. S., Lee, Y. H., and Wang, T.: Three-dimensional variational assimilation of MODIS aerosol optical depth: implementation and application to a dust storm over East Asia, J. Geophys. Res., 116, D23206, https://doi.org/10.1029/2011JD016159, 2011 b.

Lucht, W., Schaaf, C. B., and Strahler, A. H.: An algorithm for the retrieval of albedo from space using semiempirical BRDF models, IEEE T. Geosci. Remote Sens., 38, 977-998, 2000.

Mikami, M., Shi, G., Uno, I., Yabuki, S., Iwasaka, Y., Yasui, M., Aoki, T., Tanaka, T.Y., Kurosaki, Y., Masuda, K., Uchiyama, A., Matsuki, A., Sakai, T., Takemi, T., Nakawo, M., Seino, N., Ishizuka, M., Satake, S., Fujita, K., Hara, Y., Kai, K., Kanayama, S., Hayashi, M., Du, M., Kanai, Y., Yamada, Y., Zhang, X.Y., Shen, Z., Zhou, H., Abe, O., Nagai, T., Tsutsumi, Y., Chiba, M., and Suzuki, J.: Aeolian dust experiment on climate impact: An overview of Japan-China joint project ADEC, Global Planet. Change, 52, 142-172, https://doi.org/10.1016/j.gloplacha.2006.03.001, 2006.

Minnis, P., Mayor, S., Smith, W. L., and Young, D. F.: Asymmetry in the diurnal variation of surface albedo, IEEE T. Geosci. Remote Sens., 35, 879-891, https://doi.org/10.1109/36.602530, 1997.

Mlawer, E. J., Taubman, S. J., Brown, P. D., Iacono, M. J., and Clough, S. A.: Radiative transfer for inhomogeneous atmospheres: RRTM, a validated correlated-k model for the longwave, J. Geophys. Res., 102, 16663-16682, https://doi.org/10.1029/97JD00237, 1997.

Otto, S., de Reus, M., Trautmann, T., Thomas, A., Wendisch, M., and Borrmann, S.: Atmospheric radiative effects of an in situ measured Saharan dust plume and the role of large particles, Atmos. Chem. Phys., 7, 4887-4903, https://doi.org/10.5194/acp-74887-2007, 2007.

Parrish, D. F. and Derber, J. C.: The National Meteorological Center's spectral statistical interpolation analysis system, Mon. Weather Rev., 120, 1747-1763, https://doi.org/10.1175/15200493(1992)120<1747:TNMCSS>2.0.CO;2, 1992.
Ricchiazzi, P., Yang, S., Gautier, C., and Sowle, D.: SBDART: A Research and Teaching Software Tool for Plane-Parallel Radiative Transfer in the Earth's Atmosphere, B. Am. Meteorol. Soc., 79, 2101-2114, 1998.

Schaaf, C. B., Gao, F., Strahler, A. H., Lucht, W., Li, X., Tsang, T., Strugnell, N. C., Zhang, X., Jin, Y., Muller, J. P., Lewis, P., Barnsley, M., Hobson, P., Disney, M., Roberts, G., Dunderdale, M., Doll, C., d'Entremont, R. P., Hu, B., Liang, S., Privette, J. L., and Roy, D.: First operational BRDF, albedo nadir reflectance products from MODIS, Remote Sens. Environ., 83, 135-148, 2002.

Schaaf, C. and Wang, Z.: MCD43A1 MODIS/Terra+Aqua BRDF/Albedo Model Parameters Daily L3 Global $500 \mathrm{~m}$ V006, NASA EOSDIS Land Processes DAAC, https://doi.org/10.5067/MODIS/MCD43A1.006, 2015.

Schwartz, C. S., Liu, Z., Lin, H. C., and McKeen, S. A.: Simultaneous three-dimensional variational assimilation of surface fine particulate matter and MODIS aerosol optical depth, J. Geophys. Res., 117, D13202, https://doi.org/10.1029/2011JD017383, 2012.

Stapf, J., Ehrlich, A., Jäkel, E., Lüpkes, C., and Wendisch, M.: Reassessment of the common concept to derive the surface cloud radiative forcing in the Arctic: Consideration of surface albedo - cloud interactions, Atmos. Chem. Phys. Discuss., https://doi.org/10.5194/acp-2019-534, in review, 2019.

Sun, H., Pan, Z., and Liu, X.: Numerical simulation of spatialtemporal distribution of dust aerosol and its direct radiative effects on East Asian climate, J. Geophys. Res., 117, D13206, https://doi.org/10.1029/2011JD017219, 2012.

Tegen, I., Bierwirth, E., Heinold, B., Helmert, J., and Wendisch, M.: The effect of measured surface albedo on modeled Saharan dust radiative forcing, J. Geophys. Res., 115, D24312, https://doi.org/10.1029/2009JD013764, 2009.

Twomey, S.: The Influence of Pollution on the Shortwave Albedo of Clouds, J. Atmos. Sci., 34, 1149-1152, 1977.

Valenzuela, A., Olmo, F. J., Lyamani, H., Antón, M., Quirantes, A., and Alados-Arboledas, L.: Aerosol radiative forcing during African desert dust events (2005-2010) over Southeastern Spain, Atmos. Chem. Phys., 12, 10331-10351, https://doi.org/10.5194/acp-12-10331-2012, 2012.

van den Heever, S. C., Carrió, G. G., Cotton, W. R., DeMott, P. J., and Prenni, A. J.: Impacts of Nucleating Aerosol on Florida Storms. Part I: Mesoscale Simulations, J. Atmos. Sci., 63, 17521775, https://doi.org/10.1175/JAS3713.1, 2006.

Veselovskii, I., Goloub, P., Podvin, T., Bovchaliuk, V., Derimian, Y., Augustin, P., Fourmentin, M., Tanre, D., Korenskiy, M., Whiteman, D. N., Diallo, A., Ndiaye, T., Kolgotin, A., and Dubovik, O.: Retrieval of optical and physical properties of African dust from multiwavelength Raman lidar measurements during the SHADOW campaign in Senegal, Atmos. Chem. Phys., 16, 70137028, https://doi.org/10.5194/acp-16-7013-2016, 2016.

Veselovskii, I., Goloub, P., Podvin, T., Tanre, D., da Silva, A., Colarco, P., Castellanos, P., Korenskiy, M., Hu, Q., Whiteman, D. N., Pérez-Ramírez, D., Augustin, P., Fourmentin, M., and Kolgotin, A.: Characterization of smoke and dust episode over West Africa: comparison of MERRA-2 modeling with multiwavelength Mie-Raman lidar observations, Atmos. Meas. Tech., 11, 949-969, https://doi.org/10.5194/amt-11-949-2018, 2018.

Wang, D., Liang, S., He, T., Yu, Y., Schaaf, C., and Wang, Z.: Estimating daily mean land surface albedo from 
MODIS data, J. Geophys. Res.-Atmos., 120, 4825-4841, https://doi.org/10.1002/2015JD023178, 2015.

Waquet, F., Peers, F., Ducos, F., Goloub, P., Platnick, S., Riedi, J., Tanré, D., and Thieuleux, F.: Global analysis of aerosol properties above clouds, Geophys. Res. Lett., 40, 5809-5814, https://doi.org/10.1002/2013GL057482, 2013.

Wendisch, M., Pilewskie, P., Jäkel, E., Schmidt, S., Pommier, J., Howard, S., Jonsson, H. H., Guan, H., Schröder, M., and Mayer, B.: Airborne measurements of areal spectral surface albedo over different sea and land surfaces, J. Geophys. Res., 109, D08203, https://doi.org/10.1029/2003JD004392, 2004.

Wendisch, M., Hellmuth, O., Ansmann, A., Heintzenberg, J., Engelmann, R., Althausen, D., Eichler, H., Müller, D., Hu, M., Zhang, Y., and Mao, J.: Radiative and dynamic effects of absorbing aerosol particles over the Pearl River Delta, China, Atmos. Environ., 42, 6405-6416, https://doi.org/10.1016/j.atmosenv.2008.02.033, 2008.

Werner, F., Ditas, F., Siebert, H., Simmel, M., Wehner, B., Pilewskie, P., Schmeissner, T., Shaw, R. A., Hartmann, S., Wex, H., Roberts, G. C., and Wendisch, M.: Twomey effect observed from collocated microphysical and remote sensing measurements over shallow cumulus, J. Geophys. Res., 119, 1534-1545, https://doi.org/10.1002/2013JD020131, 2014.

Wu, W. S., Purser, R. J., and Parrish, D. F.: Three-dimensional variational analysis with spatially inhomogeneous covariances, Mon. Weather Rev., 130, 2905-2916, https://doi.org/10.1175/15200493(2002)130<2905:TDVAWS>2.0.CO;2, 2002.

Xia, X. and Zong, X.: Shortwave versus longwave direct radiative forcing by Taklimakan dust aerosols, Geophys. Res. Lett., 36, L07803, https://doi.org/10.1029/2009GL037237, 2009.

Xu, H., Guo, J., Wang, Y., Zhao, C., Zhang, Z., Min, M., Miao, Y., Liu, H., He, J., Zhou, S., and Zhai, P: Warming effect of dust aerosols modulated by overlapping clouds below, Atmos. Environ., 166, 393-402, https://doi.org/10.1016/j.atmosenv.2017.07.036, 2017.
Yin, Y., Wurzler, S., Levin, Z., and Reisin, T. G.: Interactions of mineral dust particles and clouds: Effects on precipitation and cloud optical properties, J. Geophys. Res., 107, 4724, https://doi.org/10.1029/2001JD001544, 2002.

Yuan, T., Chen, S., Huang, J., Wu, D., Lu, H., Zhang, G., Ma, X., Chen, Z., Luo, Y., and Ma, X.: Influence of Dynamic and Thermal Forcing on the Meridional Transport of Taklimakan Desert Dust in Spring and Summer, J. Climate, 32, 749-767, https://doi.org/10.1175/JCLI-D-18-0361.1, 2019.

Zaveri, R. A. and Peters, L. K.: A new lumped structure photochemical mechanism for large-scale applications, J. Geophys. Res., 104, 30387-30415, https://doi.org/10.1029/1999JD900876, 1999.

Zaveri, R. A., Easter, R. C., Fast, J. D., and Peters, L. K.: Model for Simulating Aerosol Interactions and Chemistry (MOSAIC), J. Geophys. Res., 113, D13204, https://doi.org/10.1029/2007JD008782, 2008.

Zhang, W., Guo, J., Miao, Y., Liu, H., Song, Y., Fang, Z., He, J., Luo, M., Yan, Y., Li, Y., and Zhai, P.: On the summertime planetary boundary layer with different thermodynamic stability in china: a radiosonde perspective, J. Climate, 31, 1451-1465, https://doi.org/10.1175/JCLI-D-17-0231.1, 2018.

Zhao, C., Liu, X., Leung, L. R., Johnson, B., McFarlane, S. A., Gustafson Jr., W. I., Fast, J. D., and Easter, R.: The spatial distribution of mineral dust and its shortwave radiative forcing over North Africa: modeling sensitivities to dust emissions and aerosol size treatments, Atmos. Chem. Phys., 10, 8821-8838, https://doi.org/10.5194/acp-10-8821-2010, 2010. 